\title{
EL DONATIVO DE LAS GUERRAS DE ITALIA (1629): ESTUDIO DEL CASO DEL ARZOBISPADO DE TOLEDO Y LA PROVINCIA DE GUADALAJARA ${ }^{1}$
}

\author{
Ramón Lanza García \\ Universidad Autónoma de Madrid
}

\begin{abstract}
RESUMEN. Uno de los expedientes utilizados en el reinado de Felipe IV para completar los recursos fiscales que exigía la ambiciosa política exterior fue la petición de ayudas extraordinarias o donativos generales, entre los cuales destaca el que se pidió en 1629 con motivo de las guerras de Italia. A pesar de su gran importancia todavía no se conocen bien su rendimiento, las formas de recaudación, las facultades o mercedes que se concedieron a particulares y comunidades, la medida en que pudo cambiar la naturaleza del sistema fiscal castellano, además de otras cuestiones no menos interesantes. El presente artículo analiza precisamente estas cuestiones en uno de los distritos en que el reino fue dividido para agilizar la administración del donativo, el arzobispado de Toledo y la provincia de Guadalajara, donde Fernando Ramírez Fariña fue comisionado por el Consejo Real y cuya documentación ofrece datos particularmente útiles y provechosos.
\end{abstract}

Palabras clave: donativo, fiscalidad, facultades, Castilla, siglo XVII.

AbSTRaCT. Extraordinary aids or donatives were one of the fiscal devices used in the reign of Phillip IV to attain the earnings that ambitious foreign policy demanded, as it was the case in 1629 on the occasion of wars of Italy. In spite of their great importance still we don't know very well the receipt, the forms of collections, the grants offered by the king and if it changed the nature of Castilian tax system. This paper just analyses these questions in the district of

1 Trabajo enviado el 16/03/2009 y admitido para su publicación el 27/04/2009. Este estudio ha sido posible gracias a la ayuda del Ministerio de Educación y Ciencia, que ha financiado el Proyecto de Investigación HAR 2008-05425, Fisco y mercado: fiscalidad, derechos de propiedad y cambio institucional en la España del siglo XVII. 
archbishopric of Toledo and the province of Guadalajara, when don Fernando Ramírez Fariña was commissioned by the Royal Council of Castile, and which records provide a rich and useful documents.

Keywords: donatives, royal finance, grants, Castile, seventeenth century

LA PETICIÓN de donativos o ayudas extraordinarias era un medio conocido, aunque en desuso, cuando Felipe IV decidió completar por esta vía los recursos fiscales que estaba exigiendo la ambiciosa política exterior de la Monarquía de España. Felipe II se había valido en 1590 de este expediente con resultados "de consideración", según Antonio Domínguez Ortiz, y asimismo Felipe III en 1603, pero al parecer con menos éxito que su padre, pues la recaudación aún no había terminado en $1612^{2}$. Entre 1624 y 1636 fueron solicitados cuatro donativos generales que proporcionaron, según el tanteo del contador Tomás de Aguilar, unos 13 millones de ducados, cifra nada despreciable si se considera el hecho de no ser un ingreso regular de la Hacienda ${ }^{3}$.

Desde el punto de vista doctrinal, el donativo era un signo de agradecimiento, un don honorario que los clientes debían a sus patrones, una gracia, un beneficio, una acción benévola que se justificaba en el mutuo intercambio de actos de reconocimiento entre vasallo y señor ${ }^{4}$. Bajo tales supuestos y a pesar del carácter aparentemente voluntario, el donativo podía ser considerado como una obligación, aunque para nada un impuesto forzoso ni mucho menos una dádiva o limosna. Sin embargo, en la práctica era fácil confundir el donativo con un servicio y el ofrecimiento voluntario con la obligación de contribuir a las cargas comunes que exigía la defensa de la comunidad. El principio de que contribuir al fisco real era una obligación de justicia estaba firmemente asentado en la doctrina jurídico política de la época, al igual que la conveniencia de consultar al reino, siquiera para determinar los medios con que debía contribuir en circunstancias extraordinarias en que así lo demandaba el rey ${ }^{5}$. A la hora de la verdad, la cuantía del donativo que se ofrecía al rey dependía del acuerdo entre

2 DOMÍngueZ ORTIZ, A.: Politica y Hacienda de Felipe IV, Madrid, Pegaso, 1983, 2ª edición, p. 281

3 ARTOLA, M.: La Hacienda del Antiguo Régimen, Madrid, Alianza,1982, p. 108. A la vista del tanteo de Tomás de Aguilar puede decirse que los donativos generales de 1624, 1629, 1632 y 1635 proporcionaron aproximadamente el $4 \%$ de todos los ingresos percibidos por la real hacienda entre 1621 y 1640 , aunque todavía faltaban varios plazos por cobrar. Si se compara con los ingresos estrictamente fiscales de la Corona de Castilla, el porcentaje sube al 10\% aproximadamente. Véase a este respecto ANDRÉS UCENDO, J.I. y LANZA GARCÍA, R.: "Estructura y evolución de los ingresos de la Hacienda Real de Castilla en el siglo XVII", Studia Histórica. Historia Moderna, 2008, pp....

4 FORTEA PÉREZ, J.I.: "Los donativos en la política fiscal de los Austrias (1625-1637): ¿servicio o beneficio?”, en RIBOT GARCÍA, L.A. y DE ROSA, L. (Dirs.): Pensamiento y política económica en la Época Moderna, Madrid, Actas, 2000, p. 41.

5 FORTEA PÉREZ, J.I.: "Los donativos en la política fiscal...”, pp. 37-38. Sobre los principios jurídico políticos del sistema fiscal de los Austrias y su evolución, véase la reciente síntesis del mismo autor: 
las partes como si se tratara de un servicio, término, por cierto, al que se refiere la documentación de modo reiterado.

Realmente es muy poco lo que todavía sabemos sobre los donativos que pidieron los Austrias y es posible que resulte muy difícil, por no decir imposible, determinar con exactitud cúal fue su rendimiento, cómo se recaudaron, quiénes contribuyeron, a qué fines respondieron y en qué medida alteraron la naturaleza del sistema fiscal castellano. De todos los donativos generales del reinado de Felipe IV quizá sea el que se pidió en 1629 con motivo de las guerras de Italia el menos conocido de todos, salvo en lo que respecta a algunos territorios, que han merecido una atención particular' ${ }^{6}$. Empezaremos nuestra pesquisa por aquí y, por razones eminentemente prácticas, dada la documentación existente, nos concentraremos en un distrito en concreto, el del consejero de Cámara Don Fernando Ramírez Fariña, que salió a pedir el donativo por el arzobispado de Toledo y la provincia de Guadalajara. El propósito de las páginas que siguen a continuación es bien sencillo, dar cuenta del valor de los ofrecimientos y de la recaudación, identificar a los contribuyentes, definir las mercedes que recibieron en virtud del servicio que hicieron y estimar las facultades de que hicieron uso, en particular las corporaciones locales, para financiar el donativo.

\section{I}

La solicitud del donativo anterior de 1625 había recaído en los corregidores, pero fuese o bien por acelerar el trámite de confirmación de facultades, requisito sin el cual era imposible proceder al pago de los ofrecimientos, o bien por otra razón desconocida, el caso es que en 1629 se decidió recurrir al procedimiento tradicional de despachar a altos funcionarios investidos de autoridad real en virtud de una comisión de carácter específico y temporal, por la cual podían dictar justicia en las áreas para las que habían sido comisionados ${ }^{7}$. En respuesta a la iniciativa del presidente de

\footnotetext{
"Négocier la nécessité: roi, royaume et fisc en Castille au temps des Habsbourg", en DUBET, A. (Coord.): Les finances royales dans la monarchie espagnole (XVIe-XIXe siècles), Rennes, 2008, pp. 259-275.

6 Aparte del citado DOMÍNGUEZ ORTIZ, A.: Política y hacienda.., p. 283 y GELABERT, J. E.: La bolsa del rey. Rey, reino y fisco en Castilla (1598-1648) Barcelona, 1997, pp. 217-226, caben destacar los comentarios respecto a Galicia y Guipúzcoa que se encuentran en EIRAS ROEL, A. (Ed.): Actas de las Juntas del Reino de Galicia, Santiago de Compostela, Xunta de Galicia, vol. II, pp. 505-509, y TRUCHUELO, S.: Gipuzkoa y el poder real en la Alta Edad Moderna, San Sebastián, Diputación Foral de Gipuzkoa, 2004, pp. 272-278. Gipuzkoa, 2004, pp. 272-278. "Sin olvidar los casos de Córdoba y Sevilla estudiados por DE BERNARDO ARES, J. M.: "Presión fiscal y bienes de propios a principios del siglo XVII", Axarquía, no 2 (1981), pp. 129-142 y MARTÍNEZ RUIZ, J. M.: Finanzas municipales y crédito público en la España Moderna. La hacienda de la ciudad de Sevilla, Ayuntamiento de Sevilla, 1992, pp. 206-208 y 311-312".

7 PIETSCHMANN, H.: Las reformas borbónicas y el sistema de intendencias en Nueva España. Un estudio político administrativo, México, FCE, 1992, p. 41.
} 
Castilla, que se había dirigido por carta a ciudades y grandes del reino en la primavera de este año exponiendo el estado de los asuntos en Europa, se había tenido una primera noticia de los ofrecimientos que estaban dispuestos a realizar, pero que luego se subrogaron en otros de mayor cuantía gracias precisamente a la intervención de los consejeros que salieron a las provincias del reino.

Cuando recibe la comisión el 22 de abril de 1629, don Fernando Ramírez Fariña es un veterano de larga experiencia en la administración de justicia, a la que se había incorporado siguiendo el ejemplo de su padre, que fue miembro de un tribunal. Consejero de Castilla desde 1616, tres años después emprendió la visita a la Chancillería de Valladolid, y el 14 de diciembre de 1622 consiguió ser miembro del Consejo de Cámara y, a la vez, asistente de Sevilla. Falleció en 1638 a los 84 años de edad con fama de hombre honrado y patrimonio modesto, hecho cierto a la vista del inventario de sus bienes personales ${ }^{8}$. En su distrito sucedió el Marqués de Jódar, quien se haría cargo de cerrar las cuentas del donativo de 1629 y de emprender el de 1636.

La documentación generada por la comisión del donativo debió de ser bastante más voluminosa que la que se ha podido localizar en los archivos nacionales. El documento fundamental es el libro de cuentas en el que se hace referencia al nombre de quien hace el donativo, la cuantía del ofrecimiento, la fecha de la obligación y los plazos en que se compromete a pagar, la relación de cédulas y provisiones donde constan las facultades o mercedes concedidas por el rey, y la forma de pago hasta su liquidación final, en que se incluye cada uno de los libramientos y cartas de pago y la forma de distribución del donativo9. En el mismo libro se alude a las escrituras de obligaciones suscritas ante el escribano de la comisión y a unos "cuadernos" originales en los que se habrían ido anotando los pormenores de la operación ${ }^{10}$. A partir de estos libros fueron elaborados los llamados libros de plazos y deudas, así como diversos sumarios. Sabemos de las consultas solicitadas por el comisario a los corregidores, de las que apenas quedan rastro, como apenas quedan tampoco de los memoriales que los particulares y las corporaciones fueron presentando a la comisión, una vez que ésta se puso en marcha anunciando por correspondencia a las villas, ciudades y lugares el estado de necesidad en que se encontraba Su Majestad y previniendo al público en general a que acudiesen a tratar el servicio que podían ofrecer ${ }^{11}$. Un último

8 Estas noticias proceden de FAYARD, J.: Los miembros del Consejo de Castilla (1621-1746), Madrid, Siglo XXI, Madrid, pp. 60, 90, 94, 120, 208, 350 y 393.

9 Archivo General de Simancas (AGS), Dirección General del tesoro (DGT), Inv. 24, legajos 1296 y 1375 , por lo que a este distrito se refiere.

10 En la cuenta de la villa de Odón se alude al "cuaderno 4, folio 695".

11 En sesión de 29 de septiembre de 1629 el ayuntamiento de la villa de Munera (Campo de Montiel) acusa recibo de una carta de don Fernando en que "por ella manda que esta villa acuda a la de El Bonillo [el] miércoles por la mañana tres de octubre, dando poder a las personas que les pareciere para 
documento es el formado con las cuentas de los depositarios a los que se había encargado la recepción del donativo ${ }^{12}$.

Tabla 1: Donativo del distrito de Fernando Ramírez Fariña, 1629

\begin{tabular}{|l|r|r|r|}
\hline & \multicolumn{1}{|c|}{ No $^{\text {Maravedíes }}$} & Porcentaje \\
\hline Todos los ofrecimientos & 856 & 402.073 .500 & 100,00 \\
\hline No Tuvieron Efecto (una hidalguía) & 60 & 43.131 .900 & 10,73 \\
\hline Hidalguías que pasaron por el Consejo de Hacienda & 20 & 31.700 .000 & 7,88 \\
\hline De otros distritos* & 2 & 4.875 .000 & 1,21 \\
\hline OFRECIMIENTOS & 774 & 322.366 .600 & 80,18 \\
\hline De los cuales, consta se pagaron & & 289.225 .893 & 89,62 \\
\hline
\end{tabular}

* Pedro Delicado, vecino de Alcalá de Guadaira, por un oficio de depositario general, y seis vecinos de Bujalance por cuatro oficios de regidor, uno de alcaide y otro de alférez mayor, todos ellos pertenecientes al distrito de Alonso de Cabrera, a cuyo libro de cuentas remite, pero donde no están. No faltan ofrecimientos de otros distritos que sí tuvieron efecto y pasaron por mano de don Fernando Ramírez Fariña.

El libro de cuentas recoge un total de 856 ofrecimientos por valor de 402.073 .500 maravedíes, aunque no todos tuvieron efecto. En realidad, los ofrecimientos correspondientes al distrito que realmente tuvieron efecto, sin contar las hidalguías, cuyo cobro pasó por mano del Consejo de Hacienda, sumaron 322.366.600 maravedíes.

Tabla 2: Donativo del distrito de Fernando Ramírez Fariña, 1629

\begin{tabular}{|l|r|r|r|r|r|}
\hline \multirow{2}{*}{} & \multicolumn{3}{|c|}{ Ofrecimientos } & \multicolumn{2}{c|}{ Pagado } \\
\cline { 2 - 6 } & \multicolumn{1}{|c|}{$\mathrm{n}^{\circ}$} & mrs & & \multicolumn{1}{c|}{ mrs } & $\%$ \\
\hline Laicos & 359 & 70.814 .255 & 21,97 & 59.260 .570 & 83,69 \\
\hline Clérigos y corporaciones eclesiásticas & 16 & 12.691 .300 & 3,94 & 2.377 .800 & 18,74 \\
\hline Corporaciones locales & 399 & 238.861 .045 & 74,09 & 227.587 .523 & 95,28 \\
\hline TOTAL & 774 & 322.366 .600 & 100,00 & 289.225 .893 & 89,72 \\
\hline
\end{tabular}

Quienes ofrecieron donativos fueron particulares laicos y corporaciones municipales, así como algunos pocos clérigos e institutos eclesiásticos. Entre los primeros hay individuos de toda condición, desde pobres hasta nobles titulados pasando por oficiales concejiles y pretendientes a serlo, licenciados y caballeros de las órdenes militares: juntos ofrecieron un quinto del total, frente a las tres cuartas partes que aportaron lugares, villas y ciudades. En consecuencia, el donativo medio de los particulares resulta ser bastante menor que el de las corporaciones: 526 ducados frente a casi 1.600 .

con su Señoría tratar con lo que esta villa podía servir a Su Majestad para la guerra que trata con el rey de Francia".

12 AGS, DGT, Inv. 24, leg. 967. 
GRÁFICO 1: Plazos anuales y patrón estacional de los pagos del donativo de 1629 en el distrito de don Fernando Ramírez Fariña
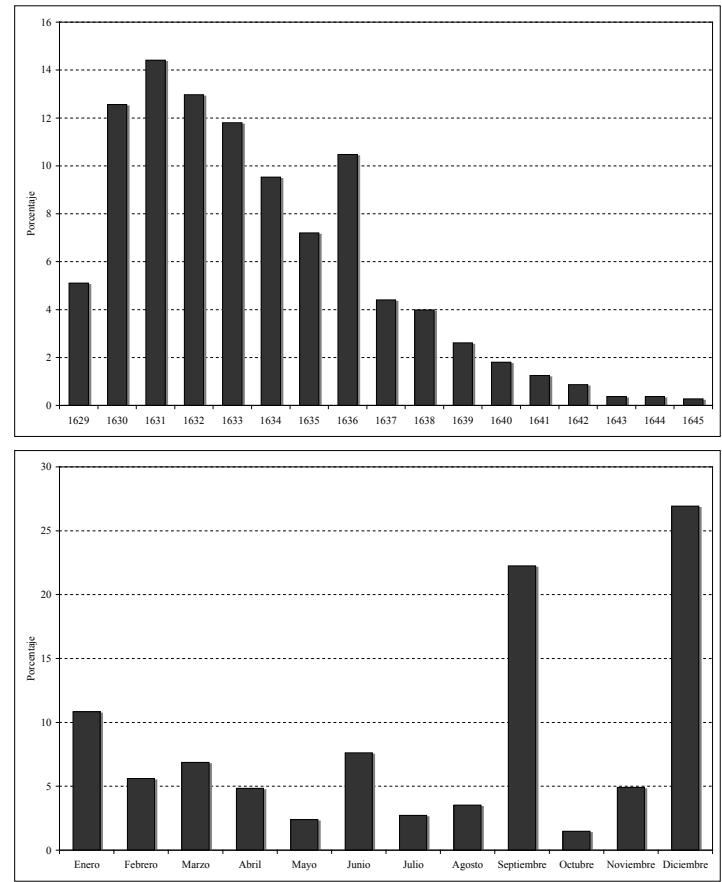

Los pagos podían hacerse al contado, como los pequeños donativos de muchos particulares, y a plazos de dos o más años, que en el caso de las corporaciones podían prolongarse hasta bien entrada la década de 1640. Naturalmente, las consiguientes facilidades de pago buscaban estimular la generosidad de los ofrecimientos, la mayoría de los cuales se hicieron efectivos antes de 1636. Por otra parte, la distribución estacional de los pagos revela un patrón definido por la concentración en el mes de septiembre y el final de año, lo cual puede ser explicado por el hecho de ser éstas las épocas en que ventas, esquilmos y rentas proporcionaban mayor liquidez a los propietarios y a la economía en general.

Una vez conocida la fecha de pago, nada impedía consignar sobre el donativo la deuda de la hacienda real ${ }^{13}$. A la hora de la verdad, el donativo de este distrito fue sin duda un éxito desde el punto de vista de la recaudación, por cuanto sólo un diez por

13 Según MARCOS MARTÍN, A.: “¿Fue la fiscalidad un factor de la crisis en la Castilla del siglo XVII?", en PARKER, G. (Ed.): La crisis de la Monarquía de Felipe IV, Barcelona, Crítica, 2006, pp. 2220 y 2222 , las consignaciones de asientos sobre los donativos subieron del 0,88\% del total en 1628-1629 al $5,46 \%$ en $1637-1638$, momento en el que coinciden los últimos plazos del donativo de 1629 con los primeros del de 1636 . 
ciento de los ofrecimientos quedó sin pagar. Las obligaciones advierten siempre que si en caso de atraso o demora fuera preciso enviar ejecutor a la cobranza de los plazos debidos deberían pagar 400 maravedíes de salario al día. Además, el impago significaba la pérdida de mercedes concedidas en virtud del donativo, como, por ejemplo, que más adelante comentaremos, la venta al mejor postor de los oficios públicos.

Los mejores pagadores, como se ve, fueron las corporaciones locales, y los peores, los eclesiásticos. En realidad, el mayor deudor es el deán y cabildo de la iglesia catedral de Toledo, que juntos habían ofrecido 24.000 ducados bajo la condición de que se trajera Breve de Su Santidad para autorizar el reparto del donativo entre los canónigos y la fábrica del templo, y la de quedar eximidos en caso de no haber guerra. A esta condición no pudieron acogerse, aunque a la primera tal vez sí. De todos modos, tampoco puede descartarse que sucediera lo mismo que en el distrito de Juan de Chaves y Mendoza, donde se reconocía que las pocas deudas que restaban por cobrar al cabo de diez años eran de eclesiásticos, contra quienes no se podía proceder en virtud de su estatuto privilegiado ${ }^{14}$.

El caso de la villa de Ocaña no puede dejar de mencionarse porque en sí mismo justifica una parte no desdeñable de los débitos de las corporaciones locales y porque fue liquidada, y no totalmente, en... 1766. Sí, casi un siglo y medio después de haber ofrecido 16.000 ducados de donativo por las guerras de Italia todavía restaba debiendo 1.286.440 maravedíes, poco más de la quinta parte, de la cual se le perdonó un tercio y se puso cobro en los dos tercios restantes en tres plazos de 428.813 maravedíes cada uno, que efectivamente pagó en octubre de 1767, 1768 y 1769. De la ciudad de Toledo consta que pagó 11.247.808 maravedíes de los 35.000 ducados con que ofreció servir, por lo que aparentemente dejó a deber un 15\%, pero justamente porque disminuyó el rendimiento de los arbitrios consignados al efecto, la ciudad decidió tomar asiento con el depositario general, que se hizo cargo de los tres últimos plazos, de modo que cabe suponer que al fin Su Majestad cobró íntegramente el donativo.

\section{II}

El donativo, cuando no es explícitamente "gracioso", cosa harto infrecuente, va acompañado por mercedes y facultades que responden a la solicitud del contribuyente y que, por lo mismo, traslucen la aspiración de conseguir determinados privilegios por medio de la gracia real ${ }^{15}$. En realidad, el donativo canaliza las peticiones que en circunstancias normales los individuos y las corporaciones habrían dirigido a los

14 AGS, DGT, In. 24, leg. 1385, y CG, leg. 3212.

15 Los donativos graciosos son 21 , todos de muy poca cuantía y 16 de vecinos de Alcalá de Henares. 
consejos de la monarquía, pero concentrándolas en el tiempo, de modo tal que puede decirse refleja el conjunto de preferencias sociales y económicas que determinan cuál es la demanda que prevalece en la sociedad castellana en un preciso momento. El donativo ofrece, así, una valiosa información a la hora de conocer hasta qué punto el ansia de honores y promoción social a través de la prestación de servicios a la Monarquía predomina sobre la búsqueda de oportunidades económicas e incentivos a la actividad productora ${ }^{16}$.

Si nos fijamos en los laicos, estos parecen preocupados, unos por el perdón de ciertas penas, algunos por ser hidalgos, otros por el derecho de propiedad y muchos, la mayoría, por el acceso a los oficios públicos. Además de estos casos, que juntos representan poco más del $90 \%$ de los ofrecimientos, cabe destacar otros de menor entidad entre los que destacan varias legitimaciones y naturalizaciones, exenciones de exámenes y licencias de diverso tipo, como casas de juegos de argolla, importar ciertas mercancías, usar coche de mulas, enseñar gramática y suplir la falta de edad para ocupar cargos y oficios públicos. El interés de las comunidades locales se centra de modo preferente en la justicia y los oficios públicos, las contribuciones y la hacienda municipal, y, por supuesto, en la propiedad comunitaria, tal y como se refleja unas veces explícita y otras implícitamente en mercedes y facultades reales. Las solicitudes de mercedes que podríamos llamar económicas, como licencias para el ejercicio de actividades mercantiles o los privilegios de mercado, además de ser pocas puede decirse que no siempre fueron reconocidas, salvo cuando se trataba de confirmar privilegios ya establecidos de antiguo. Porque, a este respecto, el donativo se atenía fielmente a las costumbres y leyes del reino.

El perdón de las penas impuestas por haber cometido ciertos delitos de carácter civil y criminal es la más llamativa de las mercedes concedidas con ocasión del donativo, pues cabe ser interpretado como un caso de justicia venal. Sin embargo, dos cosas conviene decir al respecto. La primera, que, tal y como recoge la comisión real, las dispensaciones, remisiones o perdones eran concedidos habitualmente por la Cámara en tanto en cuanto que la gracia era una potestad regia por excelencia en el antiguo régimen ${ }^{17}$. La segunda, que se trata de 70 ofrecimientos por valor de unos 72

16 Que es uno de los tópicos de la historiografía acerca de la España Moderna. Véase el ejemplo de NORTH, D.C.: Instituciones, cambio institucional y desempeño económico. México, FCE, 1993, p. 149, que citamos por su alcance internacional, entre otros muchos posibles.

17 DIOS, S. De: Gracia, merced y patronazgo real. La Cámara de Castilla entre 1474-1530, Madrid, Centro de Estudios Constitucionales, 1993, pp. 329-334. Domínguez Ortiz, Antonio, “Conmutación de penas por dinero", en Política fiscal y cambio social de la España del siglo XVII. Instituto de Estudios Fiscales, Madrid, 1984, p. 191. Señala que en la época se consideraba el delito como un litigio entre partes que podía ser resuelto mediante composición, en la que entraba naturalmente la justicia real. Este expediente volvió a ser utilizado con ocasión del donativo de 1636. 
ducados por término medio que suman 3.700.480 maravedíes, lo cual supone poco más del $1 \%$ de los donativos que tuvieron efecto y apenas el $5 \%$ de lo que ofrecieron los particulares. Entre ellos podemos encontrar desde un pobre de solemnidad condenado por haber robado 2,5 fanegas y que nada puede ofrecer, hasta los trece vecinos de El Casar de Talamanca que ofrecen 543.910 maravedíes por remitirles la pena en que habían incurrido cuando administraron los bienes de propios siendo oficiales del concejo en 1623 y $1627^{18}$.

Los donativos que implican el uso o el cambio de las condiciones de vínculos y mayorazgos son 41 casos, el 5,30\% de los que tuvieron efecto. Salvo dos, uno de los cuales es alcalde mayor, los demás son dones, caballeros y nobles titulados. Aquí encontramos las proporciones más altas de cumplimiento. La mayoría solicita merced para vender algunos bienes con el fin de subrogar el precio en otros de mayor utilidad o de amortizar una deuda, y otros, tomar ciertos capitales a censo. Solamente aparece una petición de suspender la obligación de redimir los censos que gravan el mayorazgo, solicitud que sí es bastante común en los distritos de Alonso Cabrera y Antonio Campo Redondo. En otros dos casos se plantean las tres cosas a la vez y el disponer de los bienes vinculados para suplirlos por otros libres del patrimonio. La cesión de bienes vinculados a censo en lugar de venderlos parece el resultado de las dificultades para encontrar comprador. Por último, conviene destacar los casos singulares de quienes, en virtud de sendos donativos, recibieron mercedes por las que se reconocían determinados derechos de propiedad, consiguieron revertir la concesión de oficios concejiles en su favor o lograron importantes exenciones de las localidades de sus señoríos. A esta categoría deberíamos añadir los siete casos que, no refiriéndose expresamente a vínculos o mayorazgos, sí afectan a la propiedad de personas privilegiadas que sin duda desean mejorar la propiedad, aumentar su rendimiento económico y defenderla de eventuales intrusos ${ }^{19}$.

18 No siempre se indica la causa por la que había sido condenado el solicitante del perdón, pero entre los casos conocidos son mayoría las agresiones con efusión de sangre y muerte accidental, y, en menor medida, la resistencia a la autoridad y las "cosas indebidas al oficio público". A menudo se hace mención expresa a que el acusado está perdonado de parte, lo que parece requisito para la remisión de la pena. Asimismo, los concejos de Trijueque, El Casar de Talamanca, Villarrubia de los Ojos y Beas pidieron perdón por haber tomado iniciativas sin licencia real, como sacar grano del pósito, romper baldíos, talar montes e imponer arbitrios locales.

19 El convento de San Pedro Mártir de Toledo ofreció 20 escudos de oro por la merced de aprobar un concierto con el Marqués de Malagón por el cual se acordó derribar una casa perteneciente al mayorazgo para ensanchar la entrada a la iglesia del convento. El convento de Santa Isabel de los Reyes de Toledo licencia para labrar unas tierras en la dehesa de Sielma, término de Ajofrín, "según como antiguamente se había hecho", que son 1.300 fanegas que por los años estériles en que los labradores se perdieron se había dejado de labrar y se comenzó a arrendar para hierba. La iglesia mayor colegial de Alcalá de Henares pide licencia para sacar el donativo de la común renta y mesa que se reparte a los prebendados sin que se toque a la fábrica ni a los capitales del arca mesa de ella. El colegio mayor San Ildefonso, sin perjuicio de las 
La casuística anterior apunta dos hechos bien conocidos que merecen ser destacados: uno, el endeudamiento que pesa sobre los mayorazgos y la nobleza en particular $^{20}, \mathrm{y}$, otro, el deseo de racionalizar la gestión del patrimonio mediante el sencillo procedimiento de vender los bienes más alejados del lugar de residencia y comprar otros situados más cerca. Así, por ejemplo, Don Diego Perejón Dorantes desea vender el vínculo que su mujer tiene en Pastrana y subrogarlo en Almendros o Uclés, "donde sus herederos han de vivir por tener allí su hacienda"21. Doña Ana Fernández, viuda de José Grijalva, quiere vender unos bienes situados en Cubillo, que está lejos de su residencia en Torrelaguna, y comprar "otros más útiles o que mejor se cobre su renta”. Un caso parecido es el de Don Gil Suárez Cimbrón, que no puede acudir a cultivar las 58 fanegas de sembradura, ocho de olivar y 2.000 cepas de viña valorado todo en 1.400 ducados que posee en Cabanillas, dos leguas de su residencia en Taracena, "ni encuentra quien las quiera arrendar"22.

El interés por conservar, aumentar y poner en valor el patrimonio se revela asimismo en el caso de Don Martín de Castilla y Portugal, regidor de Guadalajara, que pide licencia para labrar y sembrar un pedazo de tierra de hasta 16 y 18 fanegas, y en el del Marqués de Leganés, a quien una provisión de 22 de febrero de 1632 daba posesión de 18 fanegas en los baldíos del dicho pueblo para que pudiera hacer una huerta $^{23}$. Por último, la misma duquesa del Infantado pretendía vender casas y censos del Reino de Granada “que se iban acabando por la costa de la cobranza” y subrogar-

ventas y contratos que hasta aquí tuviere hechos de sus casas y solares, solicita poder venderlos en propiedad judicialmente a quien más diere por ellos y con el precio, comprar juros y censos. Don Vicente Ferrer que en una heredad que tiene en la villa no entre ganado vacuno en ningún tiempo del año. Bartolomé Serrano que en unas dehesas cerradas se aumente la pena al ganado que causare daño. A los Hijos y Herederos de Juan Fernández de Madrid, jurado de Toledo, una Real Provisión de 21/7/1632 les da facultad para nombrar una persona que cobre medio real por libra de seda que entrare en Toledo durante tres años para con esa renta recaudar los 6.052.720 maravedíes que les debía la Ciudad. Y, por último, el convento de Santa Fe también de Toledo pretendía nada menos que eximirse del derecho de posesión de la Mesta, pero naturalmente no tuvo efecto.

20 YUN CASALILLA, B.: "La situación económica de la aristocracia castellana durante los reinados de Felipe III y Felipe IV", en La gestión del poder. Corona y economías aristocráticas en Castilla (siglos XVI-XVIII), Madrid, Akal, 2002, pp. 163-196,

21 Las mismas razones deben mover a Don Diego de Orozco a emplear los 700 ducados en que valora la casa y las tiendas de Valdepeñas en la compra de otros bienes más útiles en Almagro.

22 Y contrario al de Don Jerónimo Flores Pacheco, alférez mayor de Almagro, que no encuentra quien las quiera comprar, sino tomándolas a censo. Don Gaspar Gutiérrez de César y Escobar pretende mejorar las casas de labranza para darlas por una renta mayor que la actual, y Don Juan Suárez de Cárcamo vender las casas principales de Toledo, valoradas en 10.600 ducados, para comprar un juro sobre las alcabalas de Baeza de 1.573.600 maravedíes de principal, que a 14 mil el millar debe rentar 112.410 maravedíes al año.

23 Se trata de las tierras situadas en los baldíos de Bustarque y Overa, en el sitio de Juan Rejón, que se le habían dado por arbitrios a la villa para ayuda de sacar los 1.000 ducados con que había servido, pero como era en perjuicio del marqués y de su jurisdicción, la villa cedió el dicho arbitrio. 
los en otros libres valorados en 1.200 ducados, además de tomar la jurisdicción de un heredamiento que tiene en Guadalajara, "que lo ha consentido el Reino y la mayor parte de las Ciudades y Villa de Voto en Cortes, atento sirve con... 6.000 ducados de donativo gracioso". Una gracia acompañada por la merced del oficio de alguacil mayor de Guadalajara, la cual, sin embargo, no tuvo efecto porque la ciudad lo compró por el tanto.

El objetivo de mejorar el patrimonio es evidente asimismo en los dos ofrecimientos que hizo el Conde de Puñonrostro, uno de 20.000 reales y otro de 1.000 ducados, y en el de Don Juan Vaca de Heredia, que alcanzó los 700 ducados. Ambos donativos iban acompañados por la merced de eximir de las cinco leguas de la Corte a las localidades de que eran señores: Alcobendas y Torrejón de Velasco, el primero, y Daganzo, el segundo ${ }^{24}$. La facultad que asimismo pedían para tomar a censo el importe del donativo se justificaba sin mayores argumentos, "pues en dar el privilegio de exención es en más valor del mayorazgo".

La propiedad de los oficios concejiles no era menos interesante, como pone de relieve el caso de la Duquesa del Infantado citado poco más arriba. Lope de Guzmán de la Serna, alcalde mayor de Villarrubia de los Ojos, pretendía convertir la venta de unos bienes vinculados en un oficio de regidor no renunciable valorado en unos 10.000 reales. El Conde de La Puebla de Montalbán ofreció 1.500 ducados por la merced de anular la que SM había hecho a Andrés Gordón Alvarado, que se había obligado por 20.000 reales por el oficio de Alguacil Mayor, que al fin se la hizo al Conde. Y el de Cantillana otros 1.150 ducados por los de fiel ejecutor y regidor de que antes se había hecho merced a ciertos particulares, el primero por 600 ducados y el segundo por 500. Ciertamente, la perspectiva de adquirir un oficio público podía incitar a ofrecer grandes donativos.

\section{III}

Como bien es sabido, la confluencia de las necesidades fiscales de la Corona y el deseo de ascenso social de las oligarquías castellanas habían impulsado la perpetuación y venta de los oficios concejiles, a pesar de las prohibiciones que al efecto habían establecido las leyes del reino ${ }^{25}$. El caso es que por vía de renunciación se había acelerado la tendencia a la patrimonialización de unos cargos públicos a los

24 La exención de las dos primeras localidades se refiere sólo al pan de registro, pero la segunda a la jurisdicción civil y criminal.

25 FORTEA, J. I.: "Las ciudades, sus oligarquías y el gobierno del Reino", en FEROS, A. y GELABERT, J. (Dirs.): España en tiempos del Quijote Madrid, Taurus, 2004, pp. 235-278, concretamente 238. 
que se accedía inicialmente por nombramiento real, con carácter vitalicio y en virtud de los méritos y servicios de los candidatos, y que por medio del acrecentamiento y la creación de nuevos oficios, las plantas del gobierno municipal conocieron sustanciales incrementos, sobre todo en los reinados de Carlos I y Felipe II $^{26}$. A estos cambios siguieron, como cabía esperar, intensos debates políticos y doctrinales en los que se trasluce una crítica general a la venalidad de los cargos públicos y una afirmación de la potestad real, si no siempre respecto a los oficios de jurisdicción y a la venta por precio, sí en cuanto a la enajenación por vía de merced o gracia real, máxima prerrogativa de la monarquía en el Antiguo Régimen. La casuística podía ser, desde luego, enormemente variada y compleja, aún más desde el momento en que la corona decidió utilizar el expediente no ya de la enajenación, sino del consumo de los oficios acrecentados. Así, la escritura del servicio de los 18 millones de 1601, que había dispuesto el consumo de los oficios acrecentados conforme fueren vacando, no cuestionaba a juicio de los letrados del reino la potestad real para disponer de los oficios públicos por merced, ni evitó las perpetuaciones de escribanías y oficios de regimientos ni las enajenaciones de oficios menores ${ }^{27}$. Algo después, la escritura del servicio de millones de 1608 y asimismo la de 1619 se limitaron a disponer que cualquier población que quisiera convertir en añales oficios que antes eran perpetuos, o viceversa, debía pedirlo en cabildo abierto y, previo consentimiento del Reino junto en Cortes, remitir al Consejo Real su propuesta para que éste tomase la decisión final.

Es en este contexto de aparente calma y estabilidad en el que se enmarcan las peticiones de perpetuación, acrecentamiento, venta y consumo de oficios que recoge el donativo de 1629, justo un año antes de que comenzara un nuevo episodio de enajenación por mano del factor general Bartolomé Spínola ${ }^{28}$. Cabe suponer que los consejeros que salieron a pedir el donativo tuvieron la ocasión de tomar el pulso a la sociedad castellana y comprobar cuál era el alcance de la demanda de oficios concejiles. Si el conde de Castrillo apenas recoge peticiones al respecto en Castilla la Vieja y don Alonso de Cabrera atiende en Andalucía la perpetuación de regimientos y la creación de oficios de alférez, alguacil y otros de carácter no jurisdiccional, don Fernando Ramírez Fariña encuentra en Castilla la Nueva un panorama algo más variado.

26 El proceso abarca algo menos de un siglo, pues si bien comienza en 1543 y termina en 1643 hubo un parón en 1601-1630. Véase GELABERT, J.: "Tráfico de oficios y gobierno de los pueblos en Castilla (1543-1643)", en RIBOT García, L.A. y DE ROSA, L. (Dirs.): Ciudad y mundo urbano en la Época Moderna, Madrid, Actas, 1997, p. 157.

27 Al menos en los años de 1609-1614 en que es posible contabilizar los asientos registrados en los libros de hacienda, según FORTEA, J. I.: "Las ciudades, sus oligarquías y el gobierno...”, p. 250. Véase también sobre esta época MARCOS MARTÍN, A.: "Las ventas de oficios en Castilla en tiempos de suspensión de las ventas (1600-1621)", Chronica Nova, n³3, 2007, pp. 13-35.

28 Datos y pormenores de esta operación en GELABERT, J.: “Tráfico de oficios...”, pp. 171-186. 
En Castilla la Nueva, y muy especialmente en el territorio de las órdenes militares, la venta de oficios públicos había tenido largo éxito en las décadas anteriores a 1629 y continuó teniéndolo todavía unos años después. Dos razones explican este hecho ${ }^{29}$. Por una parte, el crecimiento de la región que se había prolongado hasta el cambio de siglo justificaba eventualmente la necesidad de crear nuevos oficios con el fin de facilitar la administración de los asuntos locales. Por otra, la concentración del poblamiento en lugares y villas de tamaño medio facilitaba la promoción de los potenciales compradores, cosa harto difícil en las ciudades y grandes poblaciones donde la planta del gobierno municipal se encontraba sólidamente asentada desde la baja Edad Media y en los lugares pequeños donde apenas había familias acomodadas que pudieran comprar los oficios concejiles, que, por lo demás, poco atractivo podían ofrecer.

El caso es que no faltaron peticiones a nuestro ilustre consejero con ocasión del donativo de las guerras de Italia. Casi un tercio de los ofrecimientos del distrito se refieren a oficios concejiles, exactamente 254 casos, de los cuales 210 corresponden a particulares y el resto a lugares, villas y ciudades, con tres casos, 38 y otros tres, respectivamente. Estos últimos representan poco más de la décima parte de los ofrecimientos hechos por las corporaciones locales, mientras que los primeros superan más de la mitad de los que hicieron los laicos.

Los oficios enajenados pueden ser clasificados, siguiendo el criterio de Francisco Tomás y Valiente, en oficios de pluma, de poder y de dineros ${ }^{30}$. El prototipo de los oficios de pluma es naturalmente el de escribano. En la mayoría de los casos que constan en este distrito se trata de escribanos que adquieren o perpetúan una escribanía de número y ayuntamiento. Además de un título de escribano apostólico y otro de cámara, conviene destacar la merced de la escribanía de millones a la ciudad de Burgos, que debería haber correspondido al distrito de Don García de Avellaneda. En realidad, la ciudad ofreció un donativo de 2.000 ducados por un oficio del que previamente se había hecho merced a Juan de Villegas, escribano de la comisión de don Fernando Ramírez Fariña, que se lo había concedido de por vida en virtud de un donativo de 500 ducados $^{31}$. También Bernardo González, oficial de la escribanía de cámara, intentó comprar la escribanía de millones de Toledo por 2.300 ducados, pero el título que recibió por real cédula del 6 de febrero de 1630 fue rasgado. Luego

29 LÓPEZ-SALAZAR, J.: "El régimen local de los territorios de órdenes militares (ss. XVI y XVII)", en BERNARDO ARES, J.M.de y MARTÍNEZ RUIZ, E. (Ed.): El municipio en la España Moderna, Córdoba, Universidad de Córdoba, 1996, p. 291.

30 TOMÁS y VALIENTE, F.: "Ventas de oficios públicos en Castilla durante los siglos XVII y XVIII", en Gobierno e instituciones en la España del Antiguo Régimen, Madrid, Alianza, 1982, p. 158.

31 El escribano renunció naturalmente a esta merced. Por su parte, a la Real Cédula de 3 de julio de 1630 por la que se reconocía esta merced a la ciudad de Burgos le siguió otra del 12 del mismo mes y año que concedía la facultad de tomar a censo hasta en cantidad de 2.000 ducados. 
intentó lo mismo con la de Alcalá de Henares, cuyo título adquirió por otra cédula de 31 de diciembre de 1633, pero tampoco tuvo efecto porque el Reino junto en Cortes declaró que todas las ventas y mercedes que se habían hecho de escribanías de millones carecían de validez "por ser contra lo dispuesto en el capítulo de millones y como tales las declaró por ningunas". En cualquier caso, la escribanía de millones es el oficio más valorado de todos los enajenados en esta comisión ${ }^{32}$.

Entre los oficios llamados de poder destaca naturalmente el de regidor, que es el más solicitado: 93 títulos de nueva creación por vía de acrecentamiento y transformación de oficios añales en vitalicios más 65 perpetuaciones de oficios renunciables. Los demás casos hasta los 203 que hemos contabilizado responden a casuísticas diferentes, entre las que destacan las nueve compras y veintiuna revocaciones promovidas por corporaciones locales, sobre las que enseguida volveremos, y otros quince casos de muy diferente interés ${ }^{33}$. De estos últimos cabe destacar a Juan Pinedo Villarroel, regidor de Toledo, a quien se le concedió la merced graciosa de ampliarle por otra vida más las que le estuvieren hechas para que no se perdiera el oficio por falta de renunciación, la misma merced, se dice, aunque no consta como tal en el donativo, que el rey concedió a los regidores y jurados que por testimonio de escribano consta votaron a favor de los servicios de 18 millones y 12 millones y los últimos servicios de 200.000 ducados de renta y 100 hidalguías. El caso de los trece regidores de la ciudad de Guadalajara probablemente se enmarca en la misma problemática anterior, aunque es difícil de explicar, porque el documento se limita a decir que ofrecieron un donativo de 2.000 maravedíes cada uno que habrían de pagar de sus salarios. Un año después reconocía don Fernando en una consulta a Su Majestad que en los servicios que hicieron las ciudades de Toledo y Guadalajara el año de 1629 "asistiendo yo allí di cuenta a VMd de los que se habían señalado en su servicio para que se les hiciese merced"34. Uno de ellos, el regidor toledano Diego de Robles se había significado de modo particular cuando, siendo regidor fiel de juzgado, "que es ser corregidor de los dieciocho lugares que Toledo tiene por propios y montes suyos", cumplió la orden particular del rey de promover el donativo que hicieron los vecinos de esos lugares. Cabe preguntarse al hilo de estos ejemplos si la concesión de mercedes a individuos que por los cargos públicos que ocupaban debían decidir la cuantía del donativo y elegir las facultades para recaudarlo, no perseguía deliberadamente estimular a los particulares a que

32 La de Toledo fue enajenada al año siguiente por 5.808 ducados, casi el triple que el ofrecimiento de 1629. Véanse éste y los demás casos en el citado trabajo de GELABERT, J.: "Tráfico de oficios...", pp. 182-184.

33 Por ejemplo, Felipe de Ordóñez Abad adquiere el oficio de regidor de Montiel que había quedado vaco porque el titular anterior, Pedro Sánchez, no había renunciado en tiempo.

34 AHN, Consejos, leg. 7154, expte. 1. 
elevaran los ofrecimientos, o, por lo menos, a predisponerlos a votar favorablemente en el sentido que indicaba la "orden particular de Su Majestad".

Las mercedes de otros oficios de poder como los de alférez mayor y alguacil mayor son pocas - veintidós y veintiuno respectivamente, casi todos de nueva creación - si se comparan con las enajenaciones de oficios de regidor, a pesar de que el rey podía disponer con mayor liberalidad y menores obstáculos legales de unos oficios que se consideraban propiedad de la Corona. El hecho de ser oficios únicos, de los que sólo había uno por localidad, los hacía especialmente atractivos para los eventuales compradores $^{35}$. Estas mismas características presentan los oficios que implicaban el manejo de dinero y estaban vinculados con operaciones mercantiles o con el control municipal de las mismas, como eran el de corredor, depositario general y, sobre todo, fiel ejecutor, de los cuales se venden cuatro, diez y veintidós, respectivamente ${ }^{36}$.

Los pretendientes justificaban sus demandas con argumentos muy sencillos que destacan la falta de cargos públicos en relación con el vecindario de la localidad y la conveniencia de mejorar la administración de los asuntos locales mediante la creación de nuevos oficios que ellos, por sus cualidades personales, nada menos que ser gente principal y tener experiencia de gobierno, son los más indicados naturalmente para ejercer. Así, cuando Miguel de la Mata y Blas Manjón ofrecen 200 ducados cada uno por la merced de dos oficios de regidores perpetuos acrecentados en Cózar (Orden de Santiago) recuerdan que en esta villa de 400 vecinos sólo había cuatro regidores, dos añales que nombra el concejo y dos perpetuos, "con los cuales andaba la villa muy falta de gobierno y convenía a la quietud de ella y servicio de Su Magd señalase y acrecentase otros dos oficios de regimiento perpetuos con lo qual la dha villa y sus vecinos serían conservados en paz". Además, por supuesto, de que ellos mismos "eran gente principal y habían sido alcaldes y regidores y tenían entera la pertenencia y noticia de las necesidades de su gobierno"37.

Sin embargo, la creación de nuevos oficios no podía dejar indiferente a corporaciones ni particulares. Unas veces se desataba el espíritu de emulación y competencia,

35 Un caso distinto es el de los nueve alguaciles de casa y corte, de los cuales siete ofrecen un donativo de 200 ducados y otro 300 con el fin de poder nombrar un teniente que sirviera el oficio, porque ya eran mayores o estaban impedidos para ejercerlo, y el último, Doña Francisca de Prado, viuda, 1.500 ducados para "vender en cabeza de quien quisiere, atento estaba con mucha necesidad e hijas pequeñas". Un caso singular es el oficio de Alcalde de Aguas de Villanueva de la Fuente.

36 A estos deberíamos añadir el oficio de administrador del marquesado de Cenete, adquirido por la Duquesa del Infantado, seis oficios de aposentador de la villa y corte, y veintidós procuradores.

37 Algo muy parecido dijeron Pedro Fernández Pérez, Francisco Martínez Caro y Diego Martínez para explicar por qué eran necesarios otros tres títulos de regidor perpetuo en la misma villa de Cózar, además de los cuatro que había en ella, dos añales y dos perpetuos, más los que ahora se venden y el de fiel ejecutor: "estaría mejor gobernada", "son gente honrada y principal de la villa, han sido alcaldes y regidores [añales]". 
lo que daba pie a la multiplicación de los oficios, pero otras, particulares o corporaciones contradecían abiertamente las pretensiones de los compradores, de lo que podía resultar la anulación de los ofrecimientos y, en consecuencia, la conservación del estado actual. En este sentido, los donativos persiguen a veces no ya la concesión de un título o su perpetuación, sino evitar la enajenación a favor de terceros, que es el modo de mantener la posición de monopolio y de poder de los interesados. Así, los escribanos de Getafe ofrecieron 1.000 ducados y los de Villaverde 5.100 reales para revocar los dos títulos que se habían concedido por 600 ducados y 5.000 reales respectivamente. Santa Cruz de la Zarza puja con 600 ducados por la escribanía de ayuntamiento que había pretendido Cristóbal Ximénez por 5.000 reales, de modo que el oficio debía seguir siendo ejercido por la persona que nombrase el ayuntamiento. Sin embargo, el oficio se vendió por hacienda de la villa por impago y se remató en Alberto de Contreras por 4.600 reales, quedando la villa obligada a pagar el resto hasta los 600 ducados que ofreció pagar. Por suerte para ella, La Mota del Cuervo sí pagó íntegramente el donativo que ofreció porque se guardase el privilegio de la escribanía de ayuntamiento, que Alonso Sánchez Alcoholado había pretendido sin éxito ${ }^{38}$.

La competencia se acrecentaba naturalmente si los potenciales compradores estaban divididos en bandos y si la planta del gobierno municipal había sido alterada anteriormente por medio de sucesivos acrecentamientos y consumos de oficios, como era el caso precisamente de Castilla la Nueva ${ }^{39}$. La disposición, cuando no la misma iniciativa de los particulares era inmediata, justo el tiempo para concertarse entre varios acerca de su pretensión ${ }^{40}$.

En Pedro Muñoz no parece haber surgido mayor oposición a la enajenación del oficio de fiel ejecutor, la perpetuación de un regimiento con título y el acrecentamiento de siete nuevos regimientos, tal vez porque, como dicen reiteradamente los pretendientes, son "los... que Su Majestad ha mandado haya en dicha villa, además de los cuatro que había en ella con título"41. Tampoco en Cabeza Quesada (Orden de Santiago) consta oposición a la enajenación de seis regimientos perpetuos, dos de los

38 De hecho, otros doce donativos no tuvieron efecto porque los concejos o los particulares interesados alegaron ser suyos.

39 LÓPEZ-SALAZAR, J.: "El régimen local...”, p. 291 y ss.

40 Las compras parecen concertadas entre varios vecinos, pues constituye un solo donativo, si bien la cuenta distingue el compromiso de cada uno y la responsabilidad en caso de impago es individual. Además, nótese que hemos contabilizado 254 ofrecimientos en los que se consignan más de 353 oficios concejiles.

41 En Villanueva de la Fuente no hubo mayor problema en la enajenación de cuatro regimientos y el oficio de fiel ejecutor, pero la de una escribanía sí, por oposición de la villa. El de alguacil mayor tampoco tuvo efecto en este momento pero sí después, cuando otro particular aprovechó la venta del factor Spínola para subir la puja de 1.500 a 3.000 ducados. 
cuales acumulan el oficio de fiel ejecutor y el de depositario general, con la condición de que no se puedan acrecentar. En Almagro los oficios concejiles implicaron a casi veinte personas que movieron no menos de 36.000 ducados sólo con ocasión de este donativo. La villa ofreció por la vara de alguacil mayor 6.200 ducados para nombrar la persona que sirviera el oficio. En virtud de real cédula fue dada en empeño a Antonio Suárez, vecino y regidor, por 990.793 maravedíes, pero en virtud del acuerdo municipal de 7 de julio de 1636 se obligó en empeño Matías de Molina por 60.000 reales, la mitad para el rey y la mitad para el primero en quien se había empeñado la vara. El oficio de fiel ejecutor fue concedido al regidor Bartolomé Calderón de Sanabria por 1.660 ducados. Don Baltasar Vélez de Jaén pretendió el oficio de alférez mayor por 50.000 reales, pero el ofrecimiento no tuvo efecto porque se hizo merced a la villa. La perpetuación de dieciséis regimientos costó 24.000 ducados a otros tantos regidores que actuaron concertados en tres momentos diferentes, aunque inmediatos. En el primero se ofrecieron 7.200 ducados que enseguida subieron a 9.000 - a razón de 1.500 ducados por regimiento_- con la condición de no acrecentar más oficios perpetuos que estos seis y de modo y manera que, de los doce regimientos de por vida que había en el ayuntamiento y que nombraba el Consejo de Órdenes, se consumieron los seis primeros conforme fueren vacando por muerte de los poseedores y entraren los nombrados, guardando el orden de antigüedad entre los seis que quedaren de por vida y los seis que se perpetuaban y reservando el derecho de apelación en caso de litigio no ante el Consejo de Órdenes sino ante el Consejo Real o el de Cámara. $\mathrm{Al}$ instante fueron enajenados otros seis regimientos perpetuos en cabeza de otros tantos caballeros de Santiago, en principio con las mismas condiciones, pero con el resultado de que había de guardarse la antigüedad entre los seis que le habían de quedar al Consejo para nombrar y los doce que se perpetuaban. Por último, otros cuatro consortes tomaron otros tantos regimientos perpetuos en lugar de los que tenían de por vida, que habían de quedar consumidos, los cuales "son acrecentados demás de los doce que hay en la villa"42.

En otras localidades, los primeros pretendientes hubieron de transigir con otros que salieron al paso. A propósito de la perpetuación de seis oficios renunciables en

42 Los seis primeros consortes son Don Diego de Orozco, Don Francisco de Zúñiga y Oviedo, Don Juan de Molina, Don Juan Valeriano de Medrano, Baltasar Calderón de Sanabria y Doña Isabel de Molina. El segundo grupo estaba formado por el licenciado Marco Antonio de Oviedo, Don Bernardino de Ávila y de la Cueva, Don Francisco de Oviedo, Francisco Cuartal Castro, Don Juan de Peralta y Don Juan Geldre Calatayud, todos del hábito de Santiago. Y el último por Baltasar Vélez de Jaén, el capitán Sebastián Ruiz, Alonso Martínez Castellanos y Alejandro Vélez, si bien más tarde el del capitán se remató en Don Diego de Molina, cuyo fiador fue el citado Don Juan de Molina, regidor perpetuo. A partir de la documentación del Consejo de Órdenes se conoce parte de este caso, que LÓPEZ-SALAZAR, J.: "El régimen local...", p. 295, explica en términos de banderías locales. 
Santa Cruz de la Zarza surgió una clara contradicción entre los términos recogidos en la súplica y la escritura de obligación, por una parte, y el decreto de la merced, por otra, porque en la primera se entendía que debía ser "en lugar de los dos regidores añales que solía haber" y en la segunda decía "quedándose los dos añales". Aunque los pretendientes entendían que "su justicia está muy clara", aceptaron el crecimiento de otros dos oficios perpetuos, pero de una sola renunciación y con la condición de que si alguno de ellos saliere algún año de alcalde lo pudiera ser renunciando el oficio de regidor. En Villanueva de la Jara, del partido de San Clemente, se planteó también un problema pecuniario cuando ocho particulares pretendieron sendos oficios renunciables acrecentados por 800 ducados. Los regidores actuales, a cuya cabeza estaba Bernardo de Alcocer, entendían que era preciso acrecentar otros cinco regimientos para otros tantos vecinos porque "de este modo se pagase a los del consumo lo que les tocase”. ¿Qué había ocurrido? Que el citado Alcocer y consortes habían pagado en 1621 nada menos que 6.500 ducados por los trece regimientos que había consumido Gilimón de la Mota, a razón de 500 ducados cada oficio, cantidad que naturalmente reclamaban ahora que había sido aprobado el nuevo acrecentamiento. En resumen, los trece interesados deben pagar 800 ducados por oficio, los 300 para el rey y los 500 para los regidores actuales que en su momento pagaron a los que renunciaron por el consumo de sus oficios.

Otras veces, en lugar de los oficiales afectados eran los concejos quienes intervenían en la puja, pedían al rey la confirmación de los oficios concejiles o contradecían la concesión alegando o bien privilegios anteriores o bien el mismo donativo. La villa de Navalcarnero adquirió los cinco regimientos que se habían criado en la villa "para que los administre como los que hoy tiene", por elecciones anuales, del mismo modo que Villamanrique de Montiel con los cuatro regimientos que se habían acrecentado, "para que use de ellos como de cosa suya propia”. Almodóvar del Campo trató de evitar sin éxito la concesión de ocho regimientos perpetuos y un alferazgo mayor, pero sí consiguió, de acuerdo la villa por sí y estos oficiales como particulares, que se le diera por el tanto el oficio de fiel ejecutor que previamente había sido concedido a Bernardo Delgado Garcés, "atento sirvió con la misma cantidad" de 1.000 ducados. Esta parece haber sido, en fin, la forma elegida para evitar la enajenación de los oficios públicos.

La oposición a la venta y acrecentamiento de nuevos oficios de poder fue clara y firme por parte de las concejos de la ciudad de Alcaraz, los lugares de Villaminaya y Yébenes, y las villas de Beas, Carrizosa, El Toboso, La Mota del Cuervo, La Ossa, La Puebla de Don Fadrique, Las Peñas de San Pedro, Munera, Navalcarnero, Ocaña, Olmedilla, Sonseca, Villahermosa de Montiel, Villanueva de los Infantes, Villanueva del Cardete, Villarobledo y Villaseca de la Sagra. Al menos tres de estos casos resultan especialmente significativos. 
La villa de El Toboso apeló a un privilegio por el que había pagado en su momento 3.097.000 maravedíes en cuanto tuvo noticia de que Juan López de la Nieta había tratado de adquirir el oficio de alguacil mayor con voz y voto en cabeza de Diego de Cañizares. Aunque podía "fiar de su justicia" a fin de hacer guardar el contrato, las "necesidades presentes" movieron a la villa a ofrecer un donativo de 1.500 ducados por la confirmación del citado privilegio, "con calidad que no se ha de poder vender el dicho oficio de alguacil mayor con voto ni sin él ni otro alguno de depositario ni fiel ejecutor y haberse de quedar el gobierno en el estado que hoy tiene", donativo que debía sumarse al de los 14.000 ducados que había ofrecido de presente por la confirmación del privilegio de mercado ${ }^{43}$.

La villa de La Mota del Cuervo también hizo valer un privilegio que databa de cuando en 1597 se redujo el gobierno local a sólo tres regimientos añales, con la condición de que "en ningún tiempo se acrecentarían más oficios", para oponerse a la enajenación de ocho oficios de regidor y los de alférez mayor, depositario general y fiel ejecutor. Los pretendientes alegaban que, teniendo más de 700 vecinos, convenía "para el buen gobierno de la villa hubiese los dichos oficios perpetuos", y a punto estuvieron de conseguirlo si llega a prosperar el acuerdo que hizo el concejo, la justicia y regimiento de la villa el 26 de diciembre de 1629 en que renunció al citado privilegio, una renuncia que no podía ser válida sin la confirmación del concejo abierto. Cabe pensar que por esta razón el Consejo y Junta del Donativo anuló la venta de los citados oficios.

El caso de Villanueva del Cardete pone de manifiesto de modo particularmente ejemplar el enorme riesgo que corrían los concejos cuando pujaban con los particulares por evitar la enajenación de oficios públicos. Cuando la villa decidió consumir los regimientos perpetuos en 1594 recibió la merced de que no se vendiesen ni acrecentasen nuevos oficios de ayuntamiento, a pesar de lo cual se habían despachado ya seis títulos de regidores a particulares vecinos de la villa. Ésta alegaba en su favor argumentos muy poderosos de orden jurídico, político y social que literalmente consistían en que "se le ha de guardar su contrato pues de su parte ha cumplido con la paga que ofreció, y que de haber regidores perpetuos en la dicha villa se sigue en ella los mismos daños que causaron el dicho consumo, porque con el modo de insaculación con que se eligen los regidores se halla la villa muy bien gobernada y los vecinos con grande quietud, y con sólo pensar que se han criado regidores perpetuos se han levantado nuevas alteraciones y los vecinos están expuestos a infinitas [des]gracias”. Al

43 La paga debía hacerse mediante la prórroga por otros cuatro años de los mismos arbitrios que le habían sido concedidos para financiar el último donativo. Por supuesto, añadía, la venta del oficio de alguacil mayor debía cesar inmediatamente, "aunque esté despachado título". 
fin y al cabo, a pesar de todo y por evitar pleitos, la villa subió la puja de los particulares, que habían ofrecido inicialmente 500 ducados por regimiento, hasta los 4.500 ducados, cantidad por la que finalmente se obligó para revocar los oficios y darlos por consumidos. No acabó ahí el asunto, pues no pudiendo la villa pagar íntegramente el donativo fue preciso enajenar los oficios que había pretendido comprar. Con el oficio de fiel ejecutor ocurrió lo mismo: al final tuvo que ser enajenado ${ }^{44}$. Como quiera que, además, la villa había tomado a censo con facultad real hasta 50.000 ducados para la paga de la primera instancia y el consumo de oficios, tampoco pudo evitar la intervención de la hacienda local por los acreedores de la villa, concretamente por Don Lorenzo de Tejada, que había pedido ser administrador de los propios y rentas del concejo. Al fin se hizo evidente que el servicio había sido inútil y la villa perdió dineros, oficios y libertad.

\section{IV}

El donativo fue también la ocasión que aprovecharon algunas localidades para solicitar determinadas exenciones de carácter fiscal y jurisdiccional. Casi un tercio de las 399 localidades que ofrecieron servir en 1629 recibieron alguna merced en este sentido: exactamente 118, a las que debemos añadir otras ocho que lo fueron por intermediación de sus respectivos señores, Polvoranca por Don Antonio Ponce de León y Chacón, Boadilla por el Marqués de Belmonte y Collado Villalba, Alpedrete y Collado Mediano, más Valdearenas, Colmenarejo y Cercedilla por la Duquesa del Infantado. La primera y la segunda de las localidades citadas consiguieron la exención de los alcaldes de casa y corte a que estaban obligadas por encontrarse en el distrito de cinco leguas de la Corte. Las tres últimas consiguieron el privilegio de villazgo eximiéndose de los alcaldes ordinarios de las villas a las que habían pertenecido, no sin oposición. Así, por ejemplo, el ofrecimiento inicial por la exención de Valdearenas y Colmenarejo fue de 650 ducados, pero primero se bajaron 300 ducados porque este último fue contradicho por Galapagar y luego, por auto de revista de la Junta de Donativo, se reconoció la Merced a la Duquesa por otros 1.000 ducados. En cambio, el título de villa para los lugares de Collado Villalba, Alpedrete y Collado Mediano costó solamente la mitad: 500 ducados. Las ventajas de la exención debían de ser grandes cuando pueblos tan pequeños asumían servicios tan desproporcionados res-

44 Los regimientos fueron adquiridos por Juan Valentín, Alonso García Castellanos, García Villata, Juan Sánchez Celemín, Miguel Pradillo Izquierdo (4.000 reales cada uno) y Francisco Izquierdo (3.000), y el oficio de fiel ejecutor por Andrés Sánchez Botija, que hizo postura de 6.000 reales según real cédula de 10 de septiembre de 1637. 
pecto a su población y, en consecuencia, a su capacidad de pago ${ }^{45}$. Cabe preguntarse asimismo si la disposición del señor del lugar a solicitar el cambio de estatuto jurisdiccional era estrictamente graciosa. Por lo que respecta a los casos anteriormente citados, y de modo particular a la duquesa del Infantado, no lo sabemos porque la fuente es muy parca sobre este punto, si bien podemos suponer que las cosas no fueron muy diferentes a como sucedió en el lugar de Ontanaya cuando quiso eximirse de la villa de Belmonte. Aunque ofreció 31.000 reales de vellón, la merced fue contradicha inmediatamente por el Marqués de Villena y Duque de Escalona, cuyo era el lugar, pero acabó siendo aprobada seis años después, cuando el señor dio su consentimiento a cambio de un servicio de 4.000 ducados. De resultas de este "concierto", la recién estrenada villa recibió facultad para tomar a censo hasta en cantidad de 4.000 ducados para efecto de pagar el citado donativo de 31.000 reales.

Además de las citadas Boadilla y Polvoranca, algunas localidades cercanas a la villa de Madrid lograron eximirse de la jurisdicción civil y criminal de los alcaldes de corte a que estaban sujetas por encontrarse dentro de las cinco leguas de la corte, como Algete, Campo Real, Carabanchel de Abajo, Cobeña, Ciempozuelos, Daganzo de Abajo y Daganzo de Arriba, Fuentelsaz, Meco y Torrelodones, en la mayoría de las cuales se hace mención expresa a la obligación de seguir contribuyendo al abastecimiento de Madrid por medio del pan de registro.

Las mercedes relacionadas con el pan de registro de la Corte son 69, aunque es más apropiado decir que se refieren a la exención de algunas de las obligaciones que implicaba este sistema de abasto a la capital de la monarquía. Como se sabe, el pan de registro era el elemento característico del sistema de abasto en los primeros años que siguieron al establecimiento de la corte en Madrid, junto con las obligaciones del ayuntamiento sobre el alfoz a través de las "tandas", heredadas de la época medieval, y el que imponía la Casa Real para necesidades corrientes o para asegurar la provisión en algunos desplazamientos. El pan de registro de Corte consistía en el envío por los lugares de las cercanías de un cupo semanal de pan cocido que debían registrar, de ahí su nombre, en la Casa de la Panadería antes de su venta. Para hacer frente a esta obligación, los lugares debían almacenar reservas en los denominados positillos de Corte. El área de registro se fue ampliando hasta alcanzar en 1630 a más de medio millar de lugares situados en un radio que superaba los cien kilómetros desde Madrid. ${ }^{46}$

45 El documento dice que Collado Villalba tenía 30 vecinos, Alpedrete 20 y Collado Mediano 5.

46 BERNARDOS SANZ, J.U.: "Mercado y abastecimiento, 1561-1850", en PINTO CRESPO, V. y MADRAZO, S.: Madrid. Atlas histórico de la ciudad, siglos IX-XIX, Madrid, Fundación Caja Madrid/ Lundwerg Editores, 1995, p. 235. 
La petición de donativo por Su Majestad fue la ocasión que aprovecharon algunas localidades para modificar o suspender las obligaciones al respecto. Entre ellas se encuentran algunas muy cercanas a la villa como Getafe, Leganés y Villaverde, y otras muy alejadas como Illescas, Tembleque o Uclés. En la mayoría de los casos se trata de eludir la obligación de mantener un pósito particular o positillo, remitir los débitos por atrasos, rebajar los cupos asignados o conseguir la exención temporal o perpetua ${ }^{47}$. La principal causa que se aduce es precisamente la lejanía, por estar más allá de las quince leguas, ser el pan moreno y de tan mala calidad que llega deshecho a la corte y no es de utilidad ni se puede vender, por una parte, los "agravios" o cargas que pesan sobre las poblaciones. Es el caso de Uclés a propósito de la rebaja del pan de registro de doce a ocho fanegas por semana porque está más de catorce leguas de Madrid y cuando llega el pan no es de provecho, y por otra, de la suspensión de la obligación de tener positillo, porque "sólo servía de costas de alguaciles y ejecutores que iban a ver si le había". La villa de La Cabeza Quesada (Orden de Santiago) se libra de traer a la Corte cuatro fanegas de pan cada semana, porque "está quince leguas de Madrid y el pan no se gasta en la corte ni llega de manera que sea de provecho, por lo cual nunca lo llevan, sino que por su dinero buscan quien cumpla con pan y como el lugar es corto, que tiene doscientos vecinos cumplidos son muchas las vejaciones que reciben y costas que se les causan en obligarlos a llevarlo y si alguna vez lo han llevado no ha llegado de provecho y se pierde". De todos modos, ya desde mediados del siglo XVII las obligaciones fueron perdiendo importancia frente al abasto de arrieros de Ávila y Segovia, los panaderos de las localidades cercanas a la capital, como Vallecas, Vicálvaro o Villaverde, y las compras del pósito, que fue ampliando sus almacenes ${ }^{48}$.

La expansión del mercado madrileño creaba oportunidades económicas que algunas poblaciones manchegas trataron de aprovechar mediante la petición de mercedes para la comercialización del vino en condiciones especiales. Así, Consuegra, Daimiel, Esquivias y Getafe pidieron facultad para vender el vino de la tierra por caro o precioso en la Corte del mismo modo que hacían La Membrilla, Alaejos y otras poblaciones, poniendo tabernas propias y sometiéndose a la postura de los alcaldes de casa y corte. Sin embargo, las solicitudes de Consuegra y Esquivias fueron denegadas y la de Daimiel parece que no llegó a entrar en vigor ${ }^{49}$.

47 Getafe y El Olivar ofrecen dos donativos por esta causa cada una, por redimirse del positillo y por remitir algunos débitos. Son, por tanto y para ser exactos, 69 donativos y 67 localidades, entre las que contamos también Torrejón de Velasco y Daganzo, aunque la merced le fue concedida al Conde de Puñonrostro junto con la facultad de tomar a censo sobre su mayorazgo, como se dijo anteriormente.

48 BERNARDOS SANZ, J.U.: "Mercado y abastecimiento...”, p. 236. Aunque intervenido, el mercado se impone sobre la coacción.

49 Esto es lo que se dice de la facultad que Alonso de Cabrera concedió a la villa de Daimiel. En efecto, el libro de este último no aclara las cosas. 
Aparte de este conjunto de casos que tiene que ver con el abasto de la corte, las mercedes de exención fiscal fueron contadas y no nuevas, sino confirmaciones de antiguos privilegios. Así, la villa de Escalona ofreció 500 ducados por la confirmación de un privilegio de los Reyes Católicos que la libertaba de pedidos, levas y repartimientos, alojamientos de soldados y otras exacciones.

Una variante de este tipo de mercedes, aunque naturalmente de mayor alcance, son los privilegios de mercado, por cuanto constituyen esencialmente un conjunto de exenciones fiscales destinadas a reducir los costes de transacción, estimular la contratación mercantil, atraer pobladores y, en fin, ampliar las bases fiscales con alivio de los contribuyentes por medio del fomento de las actividades económicas. Cinco son las solicitudes presentadas ante don Fernando Ramírez Fariña, cuatro ex novo que son denegadas: Alcázar de San Juan, Almagro, Alcaraz y Beas, y otra de confirmación por El Toboso, cuyo reconocimiento no consta porque "hay pleito" 50 . La causa de esta oposición radica sencillamente en que los mercados francos que venían concediéndose desde 1626 podían perjudicar a los pueblos circunvecinos, contradecían abiertamente una de las condiciones del encabezamiento general de alcabalas y dificultaban el nuevo encabezamiento del uno por ciento para la paga del servicio de los 12 millones, tal y como oportunamente recordaba la Comisión de Millones en consulta a Su Majestad de 17 de abril de $1630^{51}$.

Los privilegios de villazgo habían alcanzado una difusión tal en épocas anteriores que en el reinado de Felipe IV ya quedaban pocos lugares por eximirse, al menos en los territorios de las Órdenes Militares ${ }^{52}$. No obstante, don Fernando Ramírez Fariña dio el fiat a Ciruelos (Toledo), La Hinojosa (Castil de Bayuela, Ávila), La Roda (Albacete), Tres Juncos (Belmonte), Trillo (Cifuentes), Villamayor de Santiago (Uclés) y Villarrubia de Ocaña (Ocaña). En estos casos se entiende que la primera instancia queda en la justicia local y las apelaciones se dirigen a los corregimientos respectivos, chancillerías y tribunales mayores del reino. Un resultado similar perseguía seguramente la villa de Alhambra (Campo de Montiel) cuando ofreció nada menos que 10.000 ducados por el privilegio de que no se vendiera su término, y la de Tortuero con la compra de la jurisdicción a Doña Ana Bernarda de Quirós ${ }^{53}$.

50 La villa de Alcázar de San Juan pedía concretamente un mercado franco los viernes de cada semana en que los contratos paguen $1 \%$ de alcabala y los mismos derechos que en los mercados de Ciudad Real, Ocaña y Pastrana, así como la recaudación de los derechos del peso y el nombramiento de corredores, y, por último pero no menos importante, la perpetuación de alcabalas.

51 AHN, Consejos, leg. 7153, expte. 14, carpeta 1.

52 LÓPEZ-SALAZAR, J.: "El régimen local de los territorios de órdenes militares...", pp. 286288. En general, NADER, H.: Liberty in Absolutist Spain. The Habsburg Sale of Towns, 1516-1700, Baltimore, John Hopkins University Press, 1990.

53 Quien en contrapartida recibió la facultad para subrogar el precio en la compra en otros bienes que debía incorporar al vínculo y mayorazgo. 
Algunas localidades se limitaron a solicitar la primera instancia o el aumento de la cuantía de los casos que podían conocer, como, por ejemplo, El Casar de Escalona, Carmena, Quismondo y Val de Santo Domingo (Maqueda), “como se han subido en otras jurisdicciones", añadían ${ }^{54}$. En el mismo sentido cabe señalar los casos de varios lugares de los Montes de Toledo como Escalonilla, Polan y Mazarambroz ${ }^{55}$, además de otros que hicieron saber los agravios que recibían de la justicia de la ciudad de Toledo, concretamente del fiel del juzgado, que era un regidor, como el Diego de Robles citado anteriormente, que conocía en las causas civiles y criminales en los lugares de su jurisdicción, se entrometía en la primera instancia y cargaba a los pueblos y particulares con elevadas costas judiciales. Tales son los casos de Villamiel, Yébenes, Ventas de Peña Aguilera, Margaliza y Navalmoral de los Montes ${ }^{56}$. Por su parte, la ciudad de Alcaraz solicitaba que en las villas del partido puedan elegir las partes el hacer la primera apelación ante el corregidor, "porque se gastaría más en irlos a seguir a la Chancillería que montaba el interés de ello [los pleitos]"57. Por el contrario, La Puebla de Don Fadrique ofreció un donativo de 5.000 ducados para que el Consejo de Órdenes o la Chancillería de Granada conocieran en segunda instancia en lugar del Gobernador y Alcalde Mayor de Ocaña, pues como quiera que "el Consejo de Órdenes está tan cercano como se sabe y a la Chancillería de Granada van asimismo de todos los lugares realengos y de órdenes que están en su distrito,... se evitarán grandes molestias y vejaciones que la Villa padece con las justicias y algua-

54 El Casar de Escalona recibe merced para que la justicia del lugar, como conocía de 600 maravedíes abajo en causas civiles, pueda conocer en primera instancia hasta 3.000 y los alcaldes ordinarios "nombrar curadores y tutores, con que los cargos no tengan penas corporales, destierro ni suspensión de oficios ni que haya habido efusión de sangre ni palabra ni obra afrentosa, y en las demás causas puedan prender y hacer información, y que no les saquen los presos por las causas que puedan conocer". Los tres lugares añadían la cláusula de que no se entrometa la villa de Maqueda, a cuya jurisdicción pertenecían.

55 La justicia de este lugar también pretendía el hacer información y prender en las causas criminales ligeras, apartando a los alcaldes de la Hermandad de Toledo para que no se entrometieran sino en los casos que tocaren a la Hermandad.

56 Villamiel pretendía que el corregidor de Toledo por causas ligeras criminales que sucediesen en el lugar no envíe a prender ni hacer causas, especialmente no habiendo querella de parte, y que se moderasen los salarios de escribanos y alguaciles. El lugar de Yébenes, que no saque trigo ni cebada ni ganados a los vecinos sin expreso mandato del Consejo, "para que con esto cesen los agravios notorios que reciben viniendo el regidor que es el fiel del juzgado o otra justicia de Toledo y descerrejando las casas, llevándoles el trigo y cebada por fuerza, y que la justicia y fiel de Toledo no envíen ejecutor en causas civiles ni criminales, sino que guarden la Pragmática del año 1623, pues hay alcaldes y alguaciles en el lugar a quien se puede mandar y cometer cualquier ejecución. Ventas de Peña Aguilera, que la ciudad de Toledo no envíe alguaciles ni ejecutores a hacer ejecuciones ni otras diligencias en causas civiles, sino que lo cometa a la justicia o alguacil del citado lugar. Margaliza, que no lleven los presos a Toledo. Por último, Navalmoral de los Montes, que el fiel no se entrometa en conocer sobre el contenido de la provisión.

57 El lugar de Viveros, de la jurisdicción de Alcaraz, se limitaba a pedir que se apremie al corregidor de la ciudad a dictar sentencia en un pleito. 
ciles y otros que se hacen de Ocaña, que son tales que sin duda se despoblara la dicha Villa si este remedio no se pone en ello" 58.

Sean los lugares de los Montes de Toledo, las localidades promovidas por sus señores o cualesquiera otras, las causas que subyacen en la reclamación de la primera instancia parecen ser ya no el crecimiento demográfico, como había sucedido hasta las décadas finales del siglo XVI, sino la consolidación de unas oligarquías que deseaban emular a sus convecinas en el ejercicio de la autonomía local, pero también, y sobre todo, las vejaciones y costas judiciales que se derivaban de la sujeción a una jurisdicción urbana superior. De ahí la solicitud de primera instancia, de elevar el límite hasta el que podían conocer los alcaldes ordinarios o de exigir el cumplimiento de las condiciones acerca de las visitas de términos. Uno de los resultados de este fenómeno fue naturalmente la descentralización de las competencias judiciales y, en consecuencia, una reducción de los costes de transacción para los litigantes. Sin embargo, es dudoso que por este medio cesaran o desaparecieran los vicios habituales de la administración de justicia ${ }^{59}$, pero sí parece cierto que los costes para la hacienda local debieron de ser considerables.

\section{V}

El donativo que en principio debía proporcionar ingresos inmediatos a la Hacienda Real para ser administrados al margen de las Cortes acaba convirtiéndose en la práctica en un servicio ${ }^{60}$. Así, desde la proposición hasta la cobranza volvió a plantearse la misma lógica que había tenido la negociación del servicio de millones. Las obligaciones de pago fueron seguidas por la concesión de facultades para financiar los ofrecimientos, facultades sin las que era ocioso esperar el cumplimiento del donativo. Las mismas corporaciones locales eligieron, a veces previo debate en cabildo abierto, los arbitrios y medios de recaudación, que podían ser de diversa naturaleza, no necesariamente fiscal, sino patrimonial, como de hecho lo fue en la mayoría de los casos.

Como en el pago de los servicios, el donativo podía conducir a la emisión de deuda en forma de censos para cuyo pago se consignaban ciertos arbitrios durante un tiempo limitado y para este fin específico ${ }^{61}$. Aunque los plazos del donativo podían

58 A lo que añadía un recordatorio en el sentido de que la persona comisionada por el Consejo de Órdenes tenga obligación de guardar a propósito de las visitas todo lo que el dicho gobernador de Ocaña o su alcalde mayor debían guardar en conformidad de los privilegios, provisiones y cartas acordadas.

59 Por lo que respecta al territorio de órdenes, véase el ya citado estudio de LÓPEZ-SALAZAR, J.: "El régimen local...", p. 288.

60 FORTEA, J. I.: “Los donativos...”, p. 64.

61 RUIZ MARTÍN, F.: "Procedimientos crediticios para la recaudación de tributos fiscales en las ciudades castellanas durante los siglos XVI y XVII: el caso de Valladolid”, en OTAZU, A. de (Ed.): Dinero y credito (Siglos XVI al XIX), Madrid, Moneda y Crédito, 1978, pp. 37-47. 
ser prolongados con el fin de facilitar el ajuste respecto al rendimiento de los arbitrios, los pueblos preveían la necesidad de endeudarse, "atento los plazos de la paga son más cortos que los plazos de los arbitrios”, decían en Alcázar de San Juan, o, como añadían en Torrejón de Velasco, "porque de otra manera no sabe si podría cumplir a los plazos". Sin embargo, no siempre se recurre a la deuda ni aparecen tributos fiscales sobre el consumo y las personas, ni mucho menos. Las comunidades que reciben facultad expresa por medio de real cédula para tomar a censo sobre los bienes de propios son nada más que 46 respecto a 399 y otras 14 las que aluden al empleo de "lo que hubieren tomado a censo". No obstante, es posible que a este respecto el libro de cuentas omita información, que los pueblos la solicitaran por una vía distinta y para otros fines, además del donativo, o que trataran de no incrementar un endeudamiento ya preocupante ${ }^{62}$. De hecho, son 99 los pueblos que reciben la merced de poder emplear las sobras de los arbitrios en la redención de censos que habían tomado previamente con facultad real y algunos declaran estar ya tan endeudados que solicitan expresamente la reconversión de la deuda. De este modo, Marchamalo espera reducir los réditos de 11.500 ducados de censos que a razón de veinte el millar gravan los propios de la villa en un censo a menor interés, con que no bajasen de veintidós el millar. Asimismo, Torrijos, que había tomado un censo al patronazgo de Pedro de Quero, vecino de Maqueda, para pagar a SM el valor de los oficios del almotacenazgo, solicita "subir o tomar otro censo con que se quite el otro... para que mientras no se quitare el principal del censo sean menos los réditos"63. Villanueva de la Fuente solicita posponer el pago de la deuda municipal por diez años hasta finalizar el pago del donativo, a pesar del concurso de acreedores, "transfiriéndose la acción de los acreedores para los años siguientes cumplidos los dichos diez años". Y como éste otros muchos reciben asimismo merced para que los acreedores no tengan derecho sobre el producto de los arbitrios que habían impuesto para la paga del donativo.

Los medios de financiación eran efectivamente muy variados, aunque bien conocidos de los pueblos, pues venían siendo utilizados tradicionalmente en cuantos servicios había demandado la corona. El arbitrio más socorrido era sin duda el uso y explotación de la propiedad comunitaria a través sobre todo del arriendo al mejor postor de los llamados bienes de propios, la explotación de los montes para leña, monta-

62 Sobre el alcance y variantes de este problema, véase el reciente estudio de MARCOS MARTÍN, A.: "Hipotecar la hacienda común. Enajenaciones del patrimonio regio y endeudamiento municipal en los siglos XVI y XVII", en DIOS, S. de, INFANTE, J., ROBLEDO, R. y TORIJANO, E. (Coords.): Historia de la Propiedad. Crédito y Garantía, Madrid, Servicio de Estudios del Colegio de Registradores, 2007, pp. 161-210, concretamente p. 189, a propósito de los gastos en que incurrieron varios pueblos de órdenes militares después de 1587, cuando les fue devuelta la jurisdición a primera instancia que en 1566 les había sido arrebatada en beneficio de los gobernadores con el pretexto de la mala administración de justicia.

63 La real cédula de 26 de diciembre de 1629 da facultad para tomar a censo con tal que el precio no baje de 22 al millar ni suba de 33 mil el millar. 
nera y pastoreo, y, de forma poco frecuente, la venta de tierras públicas como las eras que utilizaban los vecinos privativamente durante el tiempo de la trilla, además de algún caso excepcional de licencia para enajenar bienes que habían sido hipotecados. En conjunto todos estos expedientes fueron utilizados por 269 localidades de las 399 cuyos ofrecimientos tuvieron efecto, algo más de dos tercios, si bien en la mayoría de los casos iban acompañados por facultades para hacer uso de otros arbitrios.

La aplicación de los beneficios derivados de la explotación del patrimonio comunitario al pago del donativo era una forma de eludir la presión fiscal a la que sin duda se habrían visto obligados los pueblos de no haber contado con importantes recursos económicos como eran las rastrojeras, agostaderos e invernaderos, las eras de trillar, la hoja de las viñas, los montes y los prados, dehesas, ejidos públicos y tierras baldías, que podían ser acotados en todo o en parte para pasto o labor. De los cuatro, panes y viñas predominan sobre los demás, aunque si fuera posible medir el rendimiento económico de cada uno de estos arbitrios los dos últimos serían probablemente los más valiosos.

El primero de estos expedientes alude evidentemente a la derrota de mieses, uno de los principales elementos del régimen comunal agrario tradicional. El mejor aprovechamiento de los rastrojos requería en ocasiones prolongar la redonda de las siete semanas que van desde San Juan hasta 15 de agosto, unas veces hasta Nuestra Señora de Septiembre, en Montiel, y otras hasta San Miguel, como en Carrizosa y Torre de Juan Abad, entre otras. El uso de las eras de trillar también podía ser arrendado por el tiempo que tuvieren parvas, quedando luego para los vecinos o bien para pastarlas libremente o bien para arrendar el concejo el pasto y grano ${ }^{64}$. Ante la posible oposición de los dueños de las viñas a dejar entrar el ganado en sus tierras, Villacañas previno la posibilidad de sustituir la cesión a la comunidad del derecho sobre la pámpana por un impuesto en dinero, a razón de cuatro reales por aranzada de 400 cepas. En realidad, la oposición a estos expedientes no fue pequeña si consideramos que una pragmática de 1633, en la que se regulaba el modo de conservación de pastos y dehesas, ordenaba prohibir a partir de entonces la concesión de arbitrios para arrendar el pasto común de tierras, viñas y olivares, y "los que se hubieren concedido, así para los donativos, paga de exenciones o otras compras,... cesen, habiendo cumplido el tiempo que se concedió" 65 . El derecho de la comunidad y la seguridad jurídica de los arrendatarios parecían quedar a salvo, como el interés de los ganaderos que podían disponer así de pastos gratuitos ${ }^{66}$.

64 Ballesteros (Alcaraz), y como este otra veintena de ejemplos.

65 MARCOS MARTÍN, A.: "Evolución de la propiedad pública municipal en Castilla la Vieja durante la Época Moderna”, Studia Historica. Historia Moderna, no 16, 1997, p. 90.

66 Villaminaya acuerda vender o arrendar y acotar por doce años la yerba de los prados de su término, "y ha de ser la yerba menor de dichos prados, que es desde San Miguel hasta mediado marzo, por- 
El rompimiento de tierras, ejidos o baldíos para arar y sembrar fue utilizado por 113 localidades, casi un tercio del total. Lejos de ser un expediente desconocido, ni mucho menos, la elección se justificaba porque había sido la forma de financiar otros servicios al rey y muy particularmente el primer servicio de millones de 1590, al que se refieren expresamente varias poblaciones. Como se sabe, las comunidades locales disponían de bienes públicos que eventualmente podían ser destinados a esta finalidad ${ }^{67} \mathrm{y}$, de hecho, las tierras elegidas y no otras lo fueron porque habían sido "rompidas" en otras ocasiones, tal era la fuerza de la costumbre. La mayoría de las veces se trata de pequeñas superficies, unas pocas docenas de fanegas por término medio, que hacen pensar en labradores más bien modestos. En algunos lugares y villas de escasa población dicen querer sembrar varios centenares de fanegas, hecho que bien podría reflejar la pervivencia de formas tradicionales de acceso al cultivo de la tierra antes que la presencia de grandes labradores. De todos modos, cabe afirmar que la predilección por un expediente de esta naturaleza se explica fundamentalmente porque la demanda de tierra aún se mantenía con cierto vigor, como en Andalucía, donde las facultades para el rompimiento de baldíos que estaba concediendo Alonso de Cabrera también eran importantes, y a diferencia de Castilla la Vieja, donde brillan entonces por su ausencia. Además, el derecho de la comunidad queda también a salvo de las pretensiones de los arrendatarios sobre las dehesas concejiles, de modo, como recuerdan en Villalbilla, que "no por ello adquieran posesión en ellas, sino que las puedan arrendar en cada un año a quien más diere por ellas y hacer admitir cualesquiera pujas que se hubieren libremente".

El uso de los montes para hacer leña y carbón estuvo también muy extendido, tanto que llegó a temerse una depreciación a causa del exceso de oferta. En San Martín de Valdeiglesias la corta debía hacerse con cuidado "porque se saque con más aprovechamiento, respecto de que se han tomado muchos arbitrios de ventas de montes y si todos concurriesen a venderlo no valdría tanto". Aquí, en Lillo y otras muchas localidades se establece un procedimiento muy puntilloso, por lo demás deudor de las ordenanzas reales, para hacer la poda por entre dos tierras y por los meses acostumbrados, más o menos desde San Lucas de cada año hasta el 15 de marzo del año siguiente, de modo que el espacio donde se había hecho la corta se guardase de todo ganado durante dos o tres años y del ganado mayor y cabrío otros diez o doce. Los pueblos no parecen advertir mayor peligro de una eventual deforestación que la depreciación del carbón, sino más bien las ventajas que una poda ordenada traería para los montes, que así podían regenerarse y ser más provechosos en el futuro. A este

que [después] la yerba queda para los herederos y vecinos y ganado mayor, que es desde principio de abril hasta fin de septiembre".

67 Contando con la facultad de la Corona. VASSBERG, D.E.: Tierra y sociedad en Castilla, Barcelona, Crítica, 1986, pp. 35 y 287. 
expediente recurrieron pueblos, villas y ciudades como Guadalajara, cuyos montes de La Alcarria “son tan grandiosos que son el sustento principal de la Ciudad y Tierra porque es la principal hacienda de ella", no en vano de ahí salieron 60.000 ducados para pagar los 34.000 ducados del donativo, el reparo del puente sobre el Henares y la reconstrucción de las carnicerías, entre otras cosas más. La villa de Alhóndiga esperaba obtener por este medio siete u ocho mil ducados con que pagar además del donativo, las alcabalas y otros gastos precisos del concejo.

Como ya dijimos, las ventas de bienes concejiles fueron escasísimas. Maqueda solicitó facultad para vender el monte y prado de Los Verdugales con que amortizar los 1.800 ducados que debía al Duque de Maqueda, señor de la villa que ya había iniciado el proceso de ejecución ${ }^{68}$. Por otra parte, dos villas quisieron vender las eras donde se trillaba el grano. La posesión había sido tradicionalmente vitalicia, de modo tal que al fallecer el ocupante pasaba al primer vecino que la registraba ante escribano. Con ocasión del donativo, Santorcaz se limitó a pedir la venta de por vida a las actuales poseedores y Anchuelo a perpetuidad, porque del ir "poseyendo y sucediendo los vecinos que las iban registrando... se seguían muchos inconvenientes". Sin embargo, es el único ejemplo en que la plena propiedad se justifica con el fin de evitar disputas y litigios ${ }^{69}$.

La venta de los caudales del pósito municipal es otro de los principales recursos empleados para la paga del donativo, nada menos que por 178 localidades, casi la mitad de todas ellas. La justificación que aducen reiteradamente los concejos es bien sencilla: el grano almacenado sobrepasa con creces las necesidades de los vecinos, de suerte que la mayoría solicita eximirse de la obligación de reponer el capital. Cuesta creer que los concejos no advirtieran el riesgo que la descapitalización de los pósitos suponía para los pequeños labradores, quienes a falta de este medio de crédito al consumo y la inversión quedaban a merced de los prestamistas locales, sobre todo en los años de escasez y carestía. Como quiera que el mismo expediente había sido muy utilizado para pagar el donativo de 1625 , es posible que los pueblos se encontraran sin existencias suficientes para enfrentarse a la gravísima crisis agraria que afectó a las dos Castillas desde 1630 hasta $1632^{70}$.

68 Después de haber juntado a concejo abierto, la villa solicitó licencia y facultad para venderlos al mejor postor y, así, pagar la deuda y poner las sobras en renta para propios de la villa, cosa que no se entiende cómo podía ser posible teniendo en cuenta que el valor capitalizado al $5 \%$ del arriendo de las yerbas, unos 12.000 maravedíes al año, representa solamente un tercio de la deuda.

69 En consecuencia, Anchuelo creía más conveniente "que pudiesen apropiarlas, venderlas o arrendarlas para después de los días de los que las poseían de presente y si los susodichos las quisiesen comprar en propiedad prefiriesen a los demás y no los queriendo las pudiesen vender o arrendar antes que vacasen para después de los días de los poseedores".

70 Sobre el impacto de esta crisis, véase el estudio de PÉREZ MOREDA, V.: Las crisis de mortalidad en la España interior, siglos XVI-XIX, Madrid, Siglo XXI, 1981, pp. 309-310. 
Este, como los demás arbitrios que consistían en el uso de la propiedad comunitaria, parecen característicos de economías cerradas y escasa circulación monetaria en las que era vital economizar el uso del dinero, pero la necesaria concurrencia de compradores en los mercados de pastos, tierras, leñas y granos apunta más bien en el sentido, que decíamos anteriormente, de que los pueblos trataban ante todo de evitar o minimizar el peso de las contribuciones propiamente fiscales y de recurrir a los expedientes que hicieran aflorar el capital líquido del que disponían los vecinos más acaudalados. A este respecto es muy significativa la licencia que solicitan Argamasilla de Calatrava, La Calzada de Almagro, Las Peñas de San Pedro, Lezuza, Munera y Uclés para que los oficiales de concejo puedan arrendar los bienes de propios, sin embargo de los cargos que ocupan y las leyes que lo prohíben, "por ser las personas más ricas y que tenían ganado en la dicha villa”, se justificaban los de Uclés ${ }^{71}$. En Las Peñas de San Pedro justificaban asimismo esta excepción "respecto de ser la gente más hacendada del lugar y si no se da facultad para que ellos puedan tomar a renta las dichas dehesas no habrá quien las beneficie si no es con riesgo conocido de no poder cobrar". Es cierto que en Argamasilla de Calatrava, Quero y Santa Cruz de la Zarza preveían distribuir los pastos en suertes entre los vecinos, pero no parece haber sido el caso más frecuente, ni mucho menos. Así, por cortas que fuesen las tierras públicas arrendadas al mejor postor, parece que este procedimiento contribuía a reforzar la posición de las familias de los labradores que disponían de capital para emprender el cultivo de grandes explotaciones ${ }^{72}$.

Ahora bien, la alternativa a este expediente era el aumento de las contribuciones fiscales por medio de impuestos sobre el consumo y de repartimientos personales. Al margen de lo odiosos que pudieran ser estos arbitrios, y los vecinos podían manifestarse sobre este asunto en concejo abierto, es posible que la coyuntura económica no diera muchas esperanzas acerca del rendimiento de estas especies. De ahí también la conveniencia de multiplicar las fuentes de recaudación para asegurar el pago del donativo.

Los arbitrios fiscales propiamente dichos que implican la imposición de un tributo son utilizados por 186 localidades, casi la mitad de las 399 cuyos ofrecimientos tuvieron efecto. De todos los arbitrios destacan naturalmente las sisas sobre los man-

71 Con la condición de que "este arrendamiento no se hiciese por el dicho concejo ni interviniese nadie sino sólo el gobernador de la dicha villa de Uclés". Se esperaba recaudar los 3.000 ducados del donativo en diez años con la siembra de "la ensancha" de su término y el arrendamiento a pasto del coto de Albaylle, "que otras veces había sido rompida, arada, sembrada para cotos del servicio de Su Majestad".

72 El ascenso del villano rico en esta región es tema fundamental en las obras de SALOMÓN, N.: La vida rural castellana en tiempos de Felipe II, Barcelona, Planeta, 1973, y LÓPEZ-SALAZAR, J.: Estructuras agrarias y sociedad rural en La Mancha (ss. XVI-XVII), Ciudad Real, 1986. 
tenimientos, principalmente la carne, el vino, el tocino y los pescados frescos y sala$\operatorname{dos}^{73}$, los estancos de "mercería" y las tabernas de vino, los productos de exportación y, por último pero no menos frecuente, la imposición de un celemín por fanega de trigo tomado del pósito que los deudores debían pagar cuando devolvieran el préstamo.

Los ayuntamientos podían elegir las especies sujetas a imposición de acuerdo con las condiciones económicas de cada localidad, la dotación de recursos, la demanda de la población, la especialización productiva y las posibilidades de exportación, así como la política de abastos públicos que generalmente invitaba a reforzar el tradicional proteccionismo local. Si el patrimonio concejil era pobre y el mercado de bienes de consumo rico, las sisas sobre los mantenimientos se convertían en la principal fuente de ingresos municipales con que financiar la paga del donativo. La villa de Ocaña lo expuso con absoluta claridad cuando justificaba la solicitud de introducir una sisa sobre carnes y pescados de hasta dos maravedíes por libra diciendo que los servicios que había prestado a la Corona y los gastos de obras concejiles que venía realizando, todos habían sido financiados por medio de "las dichas sisas por no tener bienes de propios ni otro arbitrio ni parte de donde sacarlo ni tener tierra ni baldíos que romper ni pastos que arrendar porque aunque tienen un monte que llaman el Monte Grande, que confina con la villa de Villatobas, no hay ni tiene otro aprovechamiento que la autoridad, señorío y jurisdicción y penas que en él se hacen de las denunciaciones... sobre el cual con los demás propios están cargados todos los censos que la villa paga". Al igual que Ocaña otras dieciséis localidades hacen uso exclusivo de los arbitrios sobre los mantenimientos, pero la mayoría recurre a estos expedientes a la vez que al patrimonio municipal.

La cuota fiscal podía ser de un maravedí y en ocasiones, como la citada anteriormente, de hasta dos maravedíes por azumbre de vino y libra de carne, tocino y pescados frescos y salados, gravamen que se añadía a las sisas reales con que se pagaban los servicios de millones, de acuerdo con la práctica habitual de la época. En consecuencia, el peso de los arbitrios municipales sobre los precios de los bienes de consumo y la demanda no debía de ser pequeño, aunque sobre este punto es mucho lo que aún resta por conocer ${ }^{74}$. Además de las sisas sobre el consumo sobre las cuatro

73 Pocas veces se mencionan otros arbitrios, impuestos o sisas sobre los bienes de consumo, como no sea de forma genérica, en cuyo caso se excluye explícitamente el pan. Las cabezas de macho y carnero podían venderse por contrapeso de su carne, de tal modo que lo que valiere de más respecto a lo que valieren enteras sea para ayuda a la paga del donativo, y si se vendieren enteras, sea el valor para el obligado de la carnicería.

74 Sobre ambas cuestiones, véase ANDRÉS UCENDO, J. I.: La fiscalidad en Castilla en el siglo XVII: los servicios de millones, 1601-1700, Bilbao, Universidad del País Vasco, 1999, pp. 115-134, y del mismo autor, "Fiscalidad real y fiscalidad municipal en Castilla durante el siglo XVII: el caso de Madrid", Investigaciones de Historia Económica, nº 5, 2006, pp. 41-70. 
especies citadas también se introducían impuestos sobre los bienes comprados por los forasteros para su exportación, como cereales y ganado en vivo, aceite, azafrán cuero, lana, madera, paños, seda y yeso, según cuales fuesen las producciones locales, de suerte que el donativo proporciona una cartografía de las actividades económicas más importantes de la región. Así, Toledo introduce un recargo de un real sobre los dos que venía gravando cada pie de jerguilla, picotes y estameñas que entraban en la ciudad y batanes de ella ${ }^{75}$.

El establecimiento de tabernas y tiendas de fruta y mercería en régimen de estanco fue otro de los expedientes al que recurrieron algunos pueblos para la paga del donativo, casi siempre acompañando a los arbitrios sobre el consumo citados anteriormente. Al igual que los bienes de propios, tiendas y tabernas eran arrendadas al mejor postor, que a cambio debía respetar las posturas del ayuntamiento. El eventual monopolio era atemperado por la concurrencia de los cosecheros del vino patrimonial, a quienes se respeta expresamente el derecho a vender en sus casas el vino de sus casas. Así, en Ocaña "todos los vecinos cosecheros de vino lo puedan vender en sus casas o otras partes como no sea en tabernas públicas al precio que bien les estuviere, conforme la calidad del vino, sin que sea necesario licencia”. Es más, el donativo podía ser la ocasión para solicitar una mayor protección del vino y de los productos locales en general, por medio o bien de la prohibición de importar vino foráneo durante la vendimia o bien de la imposición de gravámenes sobre los bienes adquiridos para la exportación, sobre todo si eran forasteros. Con este medio de empobrecer al vecino se entorpecían seguramente los intercambios mercantiles, aunque es dudoso que redundara en una mejora del abasto local de bienes de consumo.

El repartimiento entre los vecinos era el procedimiento al que recurrían necesariamente los pueblos que no tenían bienes de propios ni otra cosa de donde poder sacar el donativo, como la villa de Ontanar (Guadalajara), que decía "ser probe y muy corta". Asimismo, las grandes poblaciones como Almagro se reservaban la facultad de hacer "un repartimiento general por haciendas conforme a lo que cada uno tuviere" en caso de que los arbitrios que había elegido no bastasen a recaudar el importe del donativo, que fue lo que en efecto sucedió en 1630 y 1631 con las sisas de las carnes y el rompimiento de una dehesa, que salieron inciertos. En Campo Real, Ciruelos y La Membrilla también se esperaba ajustar el repartimiento por haciendas, pero en Bonillo fijaron un límite de dos reales por vecino, hecho que parece aludir a una capitación. De cualquier modo, el repartimiento no debía exceptuar a ningún

75 A propósito de los arbitrios municipales de la ciudad, véase NOMBELA RICO, J.M.: Auge y decadencia en la España de los Austrias: la manufactura textil de Toledo en el siglo XVII, Toledo, Ayuntamiento, 2003. 
vecino, aunque fuese privilegiado, cuando era preciso "por ser en servicio de $\mathrm{Su} \mathrm{Ma-}$ jestad y defensa de la fe, a que todos están obligados".

En contrapartida del servicio, las facultades que reciben las corporaciones locales incluyen diversas condiciones que bien podemos interpretar como otras tantas gracias y mercedes a favor de los pueblos. Además de los procedimientos de financiación a que nos hemos referido anteriormente y de la posibilidad, en absoluto despreciable, de hacer uso de unos arbitrios en lugar de otros, como conviniere a los pueblos, y de prolongar la vida de unos en caso de bajo rendimiento de los otros, las provisiones reales aluden reiteradamente a los acreedores del concejo, a los jueces de la Mesta y a las sobras que cabe esperar de los arbitrios una vez que se pague el donativo para que han sido concedidos.

El caso de Villanueva de la Fuente mencionado más arriba evidencia de qué modo el derecho de los acreedores quedaba relegado ante la urgencia de acudir al servicio real. Que no es un caso aislado lo prueba el hecho de que más de sesenta pueblos consiguieron facultades parecidas a fin de que los acreedores no tuvieran derecho sobre los rendimientos de los arbitrios que habían sido elegidos para la paga del donativo y de este modo posponer en el tiempo el pago de los réditos de la deuda municipal. La villa de Daimiel solicitaba explícitamente, y así le fue concedido, que "los acreedores que la Villa tiene hayan de esperar por la dicha cantidad prorrata conforme a sus débitos y por lo que montare cada paga al tiempo de ella y hasta que en el dicho tiempo se cumpla con Su Majestad, con que la espera la hagan todos los acreedores por otro tanto tocare a los más antiguos y modernos y a todos prorrata de lo que monta cada paga de cada uno de los dichos cuatro años y lo demás se les pague por sus antelaciones".

Las alusiones a la Mesta para que se inhiban de la administración de las tierras concejiles que han de ser arrendadas a pasto o labor revelan naturalmente el interés de los ganaderos locales en poner coto a la ganadería trashumante ${ }^{76}$. Daganzo de Arriba pide que los jueces entregadores no se entrometan en las tierras contenidas en la facultad, "ni les hagan achaques ni vejaciones ni procedan contra los vecinos, salvo en los tres casos permitidos por el principio y capítulo $1^{\circ}$, ley 7 , título 14 , Libro III, [de la] Nueva Recopilación". Una facultad del mismo tenor concedida a Pozuelo de Almagro reconoce que es preciso dejar vereda para que los ganados lleguen hasta el abrevadero. Ahora bien, quienes contradijeren la facultad, se dice en Escalona, deberán pagar una multa de 1.000 ducados. Los antecedentes previos también constituían un importante fundamento legal, porque las tierras objeto de litigio habían "sido rompidas y sembradas de ordinario", unas veces para la paga del servicio de

76 Y no un conflicto entre agricultura y ganadería locales, que eran más bien complementarias, como señala VASSBERG, D.E.: Tierra y sociedad..., p. 115. 
millones, como en La Guardia y Quer, otras para la compra de la primera instancia, como en Villahermosa de Montiel. Y, en fin, porque los tribunales ya habían fallado en el mismo sentido en los pleitos que habían promovido los alcaldes entregadores: el mismo presidente de la Mesta en Torrejón de Velasco, la Chancillería de Granada en Riopar, entre otros. La villa de Hita consideraba que no había lugar para la intromisión de "los alcaldes entregadores de mestas y cañadas" en sus tierras porque ella y sus vecinos ya "estaban absueltos y dados por libres de los rompimientos porque se causaron [los dichos pleitos]".

Por último, no deja de sorprender, hasta cierto punto, que en unos tiempos en que no cesaban las quejas por el aumento de las contribuciones, las corporaciones locales esperaban que el rendimiento de los arbitrios municipales proporcionara recursos no sólo para el servicio real, sino también para la financiación del gasto público, desde la amortización de la deuda municipal hasta la construcción de infraestructuras pasando por la atención de niños expósitos, la fundación de conventos, las fiestas patronales y otros gastos públicos de diversa naturaleza. Son numerosos los ejemplos que podemos citar para confirmar este punto, aunque por brevedad nos limitaremos a sólo tres especialmente notables.

La ciudad de Guadalajara no se limitó a ofrecer el donativo y elegir el arbitrio del carbón para pagarlo, pues con los 26.000 ducados de sobras esperaba financiar lo siguiente: la reparación de un puente, la compra de las villas eximidas de la jurisdicción de la Ciudad pocos años antes y "que Su Majestad concediere o por justicia se mandare que vuelvan a la corona real o jurisdicción de Guadalajara pagando lo que costaron y costas", la restauración de las pérdidas que había tenido la carnicería por la reforma de los precios que siguió a la baja de la moneda de 1628 y otros empeños evaluados en 6.000 ducados, además de pretender la compra de las alcabalas de la ciudad y su tierra.

El lugar de Getafe solicitó facultad para emplear las sobras en poner un bodegón, construir una fuente pública y aderezar una calle de mucho tránsito, porque “atendiendo a la mucha necesidad que en él se les ofrece a la gente forastera... y por falta de mantenimientos y ansimismo que el agua que en él ay es de pozos, salobre y dañoso para la salud de todos los que en él asisten... y que... es muy conveniente que se... derribe una parte de casas... en el sitio que llaman La Calzadilla, por ser el paso más común que en él ay como parte principal por donde se administran los enfermos el Santísimo Sacramento y a los difuntos sepultura, por ser paso tan estrecho que no tiene dos pies y medio de ancho, y para remedio y alivio de todo lo cual suplica a $\mathrm{Su}$ Majestad les conceda... licencia y facultad".

El de Madridejos es quizá el caso más interesante al respecto. Entre las once provisiones del Consejo Real del 21 de enero de 1630 a que dio lugar este donativo 
se encuentran facultades para gastar hasta 4.000 reales en las Fiestas del Santísimo Sacramento, otros 1.000 reales en alimentar, vestir y criar niños expósitos de la villa, dar hasta 30.000 maravedíes de salario al escribano de ayuntamiento "por el mucho trabajo y ocupación que tiene", redimir los censos que ha tomado con facultad real una vez pagados los 6.000 ducados con que sirve, emplear asimismo las sobras en satisfacer a los vecinos de la villa la cuarta parte de la pérdida que tuvieron en la baja de la moneda, constando lo que se perdió, y, en fin, como la plaza mayor estaba muy "desproporcionada y mal aderezada", licencia también para poder vender un solar donde construir "libremente" un cuarto de casa de 40 pies de ancho y emplear el precio, estimado en 1.000 reales, en la paga de "este servicio".

Las facultades de esta naturaleza nos ayudan a comprender la disposición de los pueblos a ofrecer y cumplir con la paga del donativo. Además de oficios, privilegios, licencias y exenciones de diverso tipo, los pueblos podían aspirar a conseguir algunas ventajas por medio de la administración de los recursos fiscales que demandaba la Hacienda Real. El acceso a los recursos de la tierra y la gestión de los bienes de propios frente a poderes intrusos, la regulación de la política de abastos, la elección de los arbitrios y aun de los plazos en que debía pagar con el fin de aliviar la carga tributaria, la implícita moratoria de la deuda municipal y la disposición de ingresos adicionales con que financiar el gasto público constituían otras tantas mercedes que las corporaciones locales estaban deseosas naturalmente de poder recibir de la Corona en justo intercambio recíproco por acudir en su ayuda con el donativo. La ocasión se prestaba de nuevo a reforzar los vínculos que unían los intereses de los gobiernos locales con los de la monarquía por medio de la fiscalidad, cuyos principios y rasgos más tradicionales venían a ser confirmados por el donativo con su dinámica de negociación sobre la cuantía y modo de pago de los ofrecimientos, de un modo parecido a como estaba sucediendo con los servicios de millones. Como estos, los donativos también podían provocar consecuencias igualmente perniciosas para la economía castellana desde el momento en que significaban un aumento de la presión fiscal -ciertamente atemperado gracias a la explotación del patrimonio comunal-, el encarecimiento de los bienes de consumo, la descapitalización de los pósitos y la escasez de crédito agrario, la limitación del gasto público, así como la inmovilización del capital privado y la consiguiente inseguridad jurídica a que se veían abocados quienes habían confiando sus ahorros a las haciendas locales, entre otras muchas consecuencias que el lector comprenderá merecen un estudio más detenido que el que hemos podido dedicarle en estas páginas. 